\title{
Gene expression analyses of immune responses in Atlantic salmon during early stages of infection by salmon louse (Lepeophtheirus salmonis) revealed bi-phasic responses coinciding with the copepod-chalimus transition
}

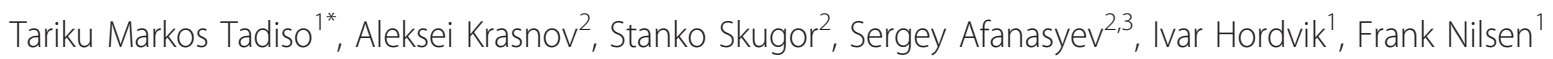

\begin{abstract}
Background: The salmon louse (Lepeophtheirus salmonis Krøyer), an ectoparasitic copepod with a complex life cycle causes significant losses in salmon aquaculture. Pesticide treatments against the parasite raise environmental concerns and their efficacy is gradually decreasing. Improvement of fish resistance to lice, through biological control methods, needs better understanding of the protective mechanisms. We used a $21 \mathrm{k}$ oligonucleotide microarray and RT-qPCR to examine the time-course of immune gene expression changes in salmon skin, spleen, and head kidney during the first 15 days after challenge, which encompassed the copepod and chalimus stages of lice development.
\end{abstract}

Results: Large scale and highly complex transcriptome responses were found already one day after infection (dpi). Many genes showed bi-phasic expression profiles with abrupt changes between 5 and $10 \mathrm{dpi}$ (the copepodchalimus transitions); the greatest fluctuations (up- and down-regulation) were seen in a large group of secretory splenic proteases with unknown roles. Rapid sensing was witnessed with induction of genes involved in innate immunity including lectins and enzymes of eicosanoid metabolism in skin and acute phase proteins in spleen. Transient (1-5 dpi) increase of T-cell receptor alpha, CD4-1, and possible regulators of lymphocyte differentiation suggested recruitment of T-cells of unidentified lineage to the skin. After $5 \mathrm{dpi}$ the magnitude of transcriptomic responses decreased markedly in skin. Up-regulation of matrix metalloproteinases in all studied organs suggested establishment of a chronic inflammatory status. Up-regulation of putative lymphocyte G0/G1 switch proteins in spleen at $5 \mathrm{dpi}$, immunoglobulins at $15 \mathrm{dpi}$; and increase of $\mathrm{IgM}$ and IgT transcripts in skin indicated an onset of adaptive humoral immune responses, whereas $\mathrm{MHCl}$ appeared to be down-regulated.

Conclusions: Atlantic salmon develops rapid local and systemic reactions to L. salmonis, which, however, do not result in substantial level of protection. The dramatic changes observed after $5 \mathrm{dpi}$ can be associated with metamorphosis of copepod, immune modulation by the parasite, or transition from innate to adaptive immune responses.

\section{Background}

The salmon louse (Lepeophtheirus salmonis Krøyer) is a widespread disease-causing marine ectoparasitic copepod infecting wild and farmed salmonids. The development of $L$. salmonis encompasses ten stages: two nauplii, a copepodid, four chalimus, two pre-adult, and

\footnotetext{
* Correspondence: tariku.tadiso@bio.uib.no

'Department of Biology, University of Bergen, Thormølhensgate 55, N-5020 Bergen, Norway

Full list of author information is available at the end of the article
}

an adult stage [1]. The nauplii hatch directly from eggstrings attached to the female lice. The two nauplii stages and the copepodid are free-living larvae that utilize yolk and other components provided maternally. The copepodid is the infectious stage of L. salmonis; its ability to settle and to recognize a relevant host is of critical importance for the parasite. We have observed that L. salmonis copepodids use $7-11$ days $\left(\right.$ at $\left.9.3^{\circ} \mathrm{C}\right)$ before they all have completed the molt to chalimus I. The four chalimus stages are physically attached to the host 
by a frontal filament. Even though an increase in virulence by $L$. salmonis has been observed as the parasite reaches the pre-adult stages [2], the chalimus stage can also account for smolt mortalities (e.g. in small pink salmon [3]). Lice damage fish by feeding on their mucus, skin, and blood and the wounds increase the risk of secondary infections. At present, L. salmonis is recognized as one of the major problems in salmon aquaculture in Norway, UK, USA, and Canada; whereas in Chile, a Caligus species (C. rogercresseyi) gives similar problems. The annual global loss due to sea lice in salmonid aquaculture is estimated to be more than 300 million USD [4]. Moreover, lice originating from farmed salmon may cause infections and mortality on wild salmonids $[4,5]$.

L. salmonis is controlled mainly by pesticides and at present only a few types are available, emamectin benzoate being the most commonly used [6]. However, increasing concerns about development of pesticide resistance, occurrence of treatment failures, and undesirable environmental impacts raise questions about the future of this strategy. The need for new methods of parasite control is fully recognized by the industry, authorities and society. At this time multiple studies assess improvement of salmon resistance to lice with an aid of selective breeding, special feeds and immune stimulants. The possibility of immunization and vaccination against $L$. salmonis infection is discussed $[7,8]$. However, protective antibody responses following repeated challenge are weak. Better understanding of acquired immune responses is essential for vaccine development. However, data on factors related to adaptive immunity are lacking in this host-parasite system $[7,9]$. Development of biological methods of protection needs better understanding of mechanisms underlying resistance to lice. The ability to suppress and reject parasites shortly after infection can be associated with innate immunity. Early innate responses are especially important since they greatly influence the subsequent responses that develop in the immune cascade. Such responses are believed to explain considerable differences between the salmonid species in susceptibility to lice [10]. Limited epithelial hyperplasia and inflammation after infection with the parasite were reported in Atlantic salmon (Salmo salar L.) and this was in contrast to highly resistant coho salmon (Oncorhynchus kisutsch) and chinook (O. nerka) salmon [11]. This can be related to inherent constraints of the immune system or its modulation by the parasite. In addition, Atlantic salmon possesses thin epidermal layer, sparsely distributed mucus cells, and exhibits low mucus lysozyme and protease activity as compared to other salmonids [12].

Knowledge of salmon immune responses to lice and their roles in protection against parasite is still limited. Until present, studies have addressed a relatively small number of immune parameters. Development of highthroughput analytical methods makes it possible to expand the search and to monitor large number of immune pathways in parallel at the gene expression level. In a previous study, we used a $1.8 \mathrm{k}$ cDNA microarray (SFA2 or immunochip) to examine the local and systemic responses of Atlantic salmon to lice within the whole infection period [13]. This platform included a relatively small number of genes and the early responses were represented with only one time-point - 3 days post infection (dpi.). In this paper we report immune related responses during the first $15 \mathrm{dpi}$, divided in five timepoints. This enabled us to see how the host is responding during the early infection period. In this study, we used the Atlantic salmon oligonucleotide platform discussed in detail in [14]. Gene expression profiling was done in skin and spleen and real-time RT-qPCR analyses were performed in these tissues, and also in the head kidney.

\section{Results}

\section{Lice count and a summary of gene expression changes}

The number of lice was determined at $15 \mathrm{dpi}$ (the last day of experiment), and high counts (58.4 \pm 9.48 lice per fish, all at chalimus I to III stage) from 100 copepodids per fish of initial infection confirmed the lack of Atlantic salmon's ability to clear the parasite. However, the microarray analyses suggested rapid and sizeable transcriptomic responses to lice. The total number of differentially expressed features was 2438 in skin and 922 in spleen (Figure 1A and Additional file 1). Given low redundancy of the platform, these numbers are close to numbers of differentially expressed genes (DEG). While the magnitude of responses remained relatively stable within the whole study period in the spleen, the number of genes with expression changes in skin decreased markedly after 5 dpi. For validation of microarray results, genes that covered the whole range of expression ratios were chosen, and RT-qPCR analyses were performed in the same individuals (Figure 1B). The results of two independent methods were in good concordance: coefficients of linear regression and correlation (Pearson $\mathrm{r}$ ) were equal to 0.84 and 0.80 respectively (complete RT-qPCR results are in Additional file 2).

Hierarchical clustering suggested high consistency of the gene expression changes (Figure 1C, D). The samples (biological replicates) were grouped by the timepoints with exclusion of one outlier (D15-1), which deviated from the common trend in both analyzed tissues. The samples from spleen and skin were divided in two large clusters (days 1-5 and days 10-15), which were sharply separated, especially in the skin. This suggested a bi-phasic response to lice and the K-mean clustering confirmed abrupt expression changes in a major part of 


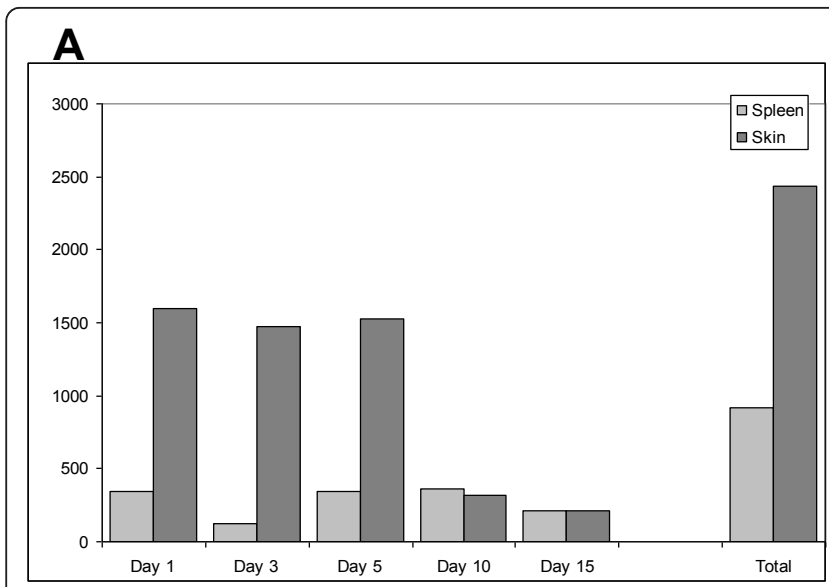

B
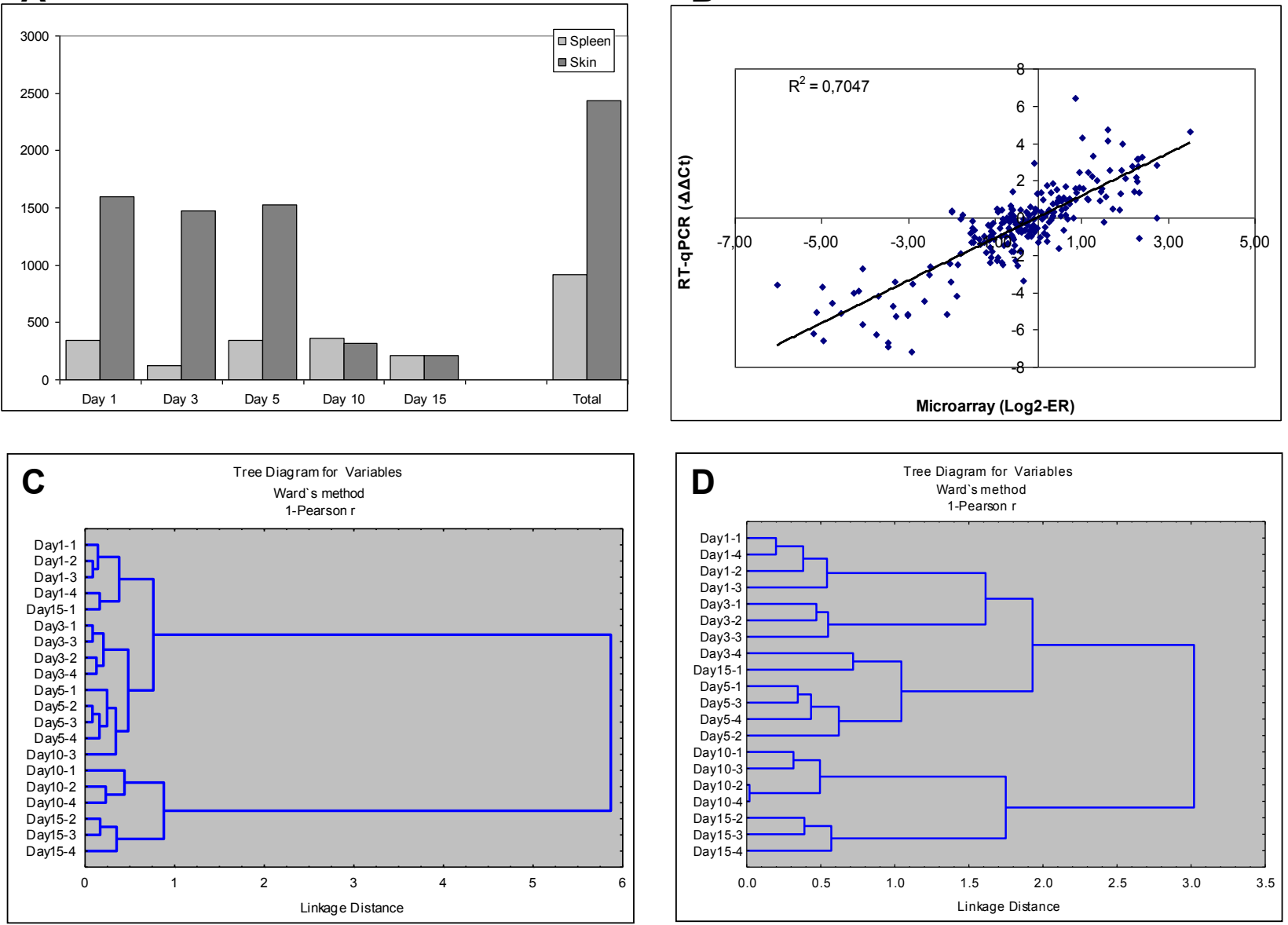

Figure 1 An overview of transcriptomic responses to lice. A: The number of differentially expressed features in skin and spleen (mean log $2^{-}$ Expression Ratio (ER) $>|0.8|, p<0.01$, one sample t-test. B: Comparison of microarray and RT-qPCR results, pooled data for 18 genes analyzed in skin and spleen, $n=225$. C, D: Hierarchical clustering of skin and spleen samples by expression profiles of DEG (Pearson $r$, Ward's method).

genes between days 5 and 10 (data not shown). A notable example of bi-phasic regulation is a group of splenic proteases (trypsins and chemotrypsins, carbopeptidases and carboxylic ester hydrolases, elastase, proteinase $\mathrm{E}$ and choriolytic enzyme) and proteins involved in regulation of exocytosis (syncollin and endoplasmic reticulum protein ERp27). The microarray results were confirmed with RT-qPCR (Figure 2 and Additional file 3).

Search for the enriched functional classes and pathways in the present microarray data illustrate the thematic associations of gene expression changes. By functions of DEG, responses to lice were much more diverse and complex in skin, which was the target site for the parasite (Table 1). The changes were associated with cell maintenance (metabolism of amino acids and sugars, mitochondrion and cytoskeleton (including motor proteins), protein biosynthesis, modification and transport, regulation of redox status, DNA replication and repair), cell communication and reparation of tissues. By result of statistical analysis, enrichment was greatest in classes related to basic metabolic functions (mitochondrion, glycolysis and ribosomes). The immune functional groups comprised a relatively small fraction of changes in the skin (only two KEGG pathways) but were predominant in the spleen (five of ten terms included in Table 1); inflammatory response and complement and coagulation cascades were the most enriched terms. The study focused on the immune responses and therefore in presentation of results preference is given to genes with known immune roles.

\section{Humoral immunity and inflammation}

Rapid responses to the parasite and transmission of signal from the damaged sites to the internal organs were confirmed with up-regulation of pro-inflammatory genes in both skin and spleen. The complement system is part of both innate and adaptive immune system, and plays a major role in recognition and elimination of pathogens. 

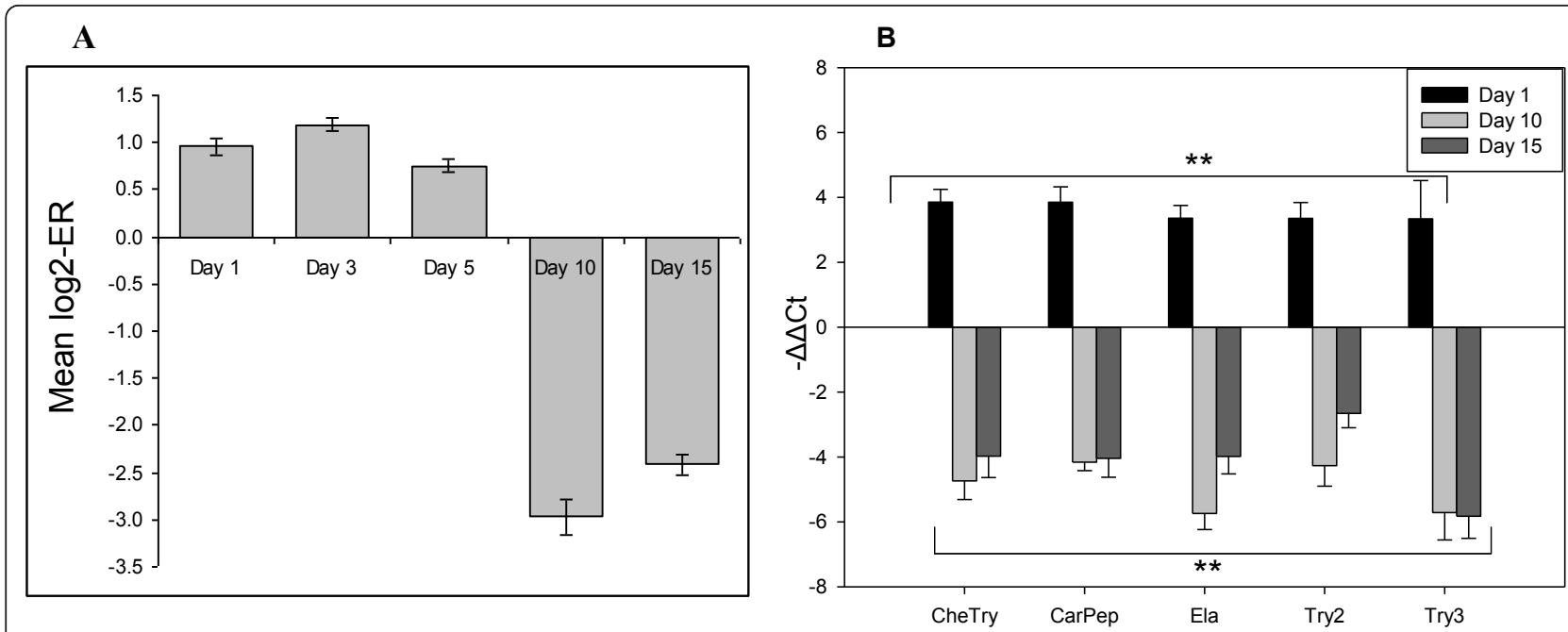

Figure 2 Expression changes of proteases in spleen. A: Microarray data are mean $\log _{2}-E R \pm$ SE for 24 genes with highly coordinated expression profiles. The lists of genes and accession numbers are in Additional file 3. B: RT-qPCR analyses performed with SYBR Green assays. Data are mean $-\Delta \Delta C t \pm S E$. Significant differences from control $(n=4, P<0.01)$ are indicated with**. Note significant differences from control of all genes at all time points. CheTry, Chemytrypsin; CarPep, Carboxypeptidase; Ela, Elastase; Try2, trypsin-2; Try3, trypsin-3.

Several lectins with early (1 dpi) induction in skin (Figure 3) have unknown roles but may be needed for detection of pathogen; the calcium dependent (C-type) lectin domain family $4 \mathrm{E}$ is expressed in macrophages and other Ag presenting cells [15]. In theory, lectins can activate one of the complement pathways. In this respect, it is noteworthy to mention down-regulation of several genes for C1Q-like proteins that can trigger the classical pathway, which could mean preferential activation of the lectin pathway. Decreased expression was shown for two negative regulators of complement: CD59 and C4b-binding protein. Phospholipase A2 and prostaglandin E synthase 3 are involved in biosynthesis of inflammatory regulators and several more immune effectors showed rapid up-regulation. The RT-qPCR analyses of IL-1B, IL-12, TNF- $\alpha$ did not find significant expression changes in skin, spleen, and head kidney (see Additional file 2). The components of the NFKB pathway changed expression in both directions while a panel of IFN-dependent proteins were down-regulated; many of these have shown strong responses to viruses [14]. Given large distance between the spleen and the skin, we could anticipate preferential regulation of genes for proteins exported to plasma and body fluids including acute phase proteins (serum amyloids, lysozyme $\mathrm{C}$ and transferrin) (Figure 4). Several lesser known proteins have been attributed to this functional group; these are jeltraxin, which is similar to C-reactive P component and serum amyloid $\mathrm{P}$ component, differentially regulated trout protein 1 [16] and LPS neutralizing protein cathelicidin. In addition, rapid up-regulation was observed in a number of possible pro-inflammatory genes including several TNF-dependent genes (TNF decoy receptor, metalloreductase STEAP4 and TSG6). In parallel, a large group of genes for plasma proteins decreased expression: highly coordinated changes were seen in the components of complement and coagulation cascade (26 genes) and in a diverse group of 55 genes that among other included apolipoproteins and glycoproteins, macroglobulins and protease inhibitors, proteins binding copper, iron and heme, scavengers, chemokines and cytokines (Figure 5A).

The temporal patterns of inflammatory changes were different in the analyzed tissues. In skin, many genes had similar expression profiles during 1-5 dpi, while in spleen the acute phase proteins showed a short-term increase only at $1 \mathrm{dpi}$. However in both skin and spleen the character of innate immune responses changed dramatically after $5 \mathrm{dpi}$. The switch of transcriptomic program was marked with abrupt temporary down-regulation of splenic plasma proteins, which was similar to that observed at $1 \mathrm{dpi}$ but with greater magnitude (Figure 5A). A hallmark of the second phase was up-regulation of several matrix metalloproteinases: MMP9 (gelatinase) and MMP13 (collagenase 3), which was observed in skin, spleen and head kidney - the latter was analyzed with RT-qPCR (Figure 5B-D). These inducible enzymes have a wide range of roles, from massive degradation of extracellular matrix and tissue remodeling to limited proteolysis and subtle regulation of immune processes $[17,18]$. Various pro-inflammatory genes including chemokines and effectors showed up-regulation after 5 dpi.

\section{Cellular responses, acquired immunity}

The gene expression profiles in skin (Figure 6A) indicated rapid alterations of the composition of immune 
Table 1 Enrichment of GO classes and KEGG pathways in the lists of DEG

\begin{tabular}{|c|c|c|c|}
\hline Functional group, pathway & Features $^{1}$ & p-value ${ }^{2}$ & Vocabulary \\
\hline \multicolumn{4}{|l|}{ Skin } \\
\hline Mitochondrion & $177 / 1104$ & 0.000 & GO \\
\hline Glycolysis / Gluconeogenesis & $33 / 117$ & 0.000 & KEGG \\
\hline Pentose phosphate pathway & $13 / 48$ & 0.009 & KEGG \\
\hline Glutamate metabolism & $16 / 48$ & 0.000 & KEGG \\
\hline Glutathione metabolism & $13 / 49$ & 0.011 & KEGG \\
\hline Ribosome & $47 / 172$ & 0.000 & $\mathrm{GO}$ \\
\hline Protein folding & $33 / 178$ & 0.015 & GO \\
\hline Protein modification & $44 / 246$ & 0.009 & $\mathrm{GO}$ \\
\hline Protein transport & $78 / 473$ & 0.004 & $\mathrm{GO}$ \\
\hline Cytoskeleton & $89 / 579$ & 0.013 & $\mathrm{GO}$ \\
\hline Myosin complex & $23 / 86$ & 0.000 & GO \\
\hline Endoplasmic reticulum & 140 / 992 & 0.027 & $\mathrm{GO}$ \\
\hline Cell redox homeostasis & $11 / 43$ & 0.027 & $\mathrm{GO}$ \\
\hline Double-strand break repair & $7 / 24$ & 0.050 & GO \\
\hline Anti-apoptosis & $41 / 200$ & 0.001 & $\mathrm{GO}$ \\
\hline Positive regulation of apoptosis & $12 / 51$ & 0.037 & $\mathrm{GO}$ \\
\hline Antigen processing and presentation ${ }^{3}$ & $17 / 69$ & 0.007 & KEGG \\
\hline Leukocyte transendothelial migration & $32 / 186$ & 0.043 & KEGG \\
\hline Cell adhesion & $83 / 545$ & 0.020 & $\mathrm{GO}$ \\
\hline Tight junction & $38 / 208$ & 0.011 & KEGG \\
\hline Heparin binding & $18 / 90$ & 0.043 & $\mathrm{GO}$ \\
\hline Keratinization & $8 / 21$ & 0.006 & $\mathrm{GO}$ \\
\hline TGF-beta signaling pathway & $24 / 113$ & 0.008 & KEGG \\
\hline \multicolumn{4}{|l|}{ Spleen } \\
\hline Inflammatory response & $22 / 213$ & 0.000 & GO \\
\hline Complement and coagulation cascades & $29 / 85$ & 0.000 & KEGG \\
\hline Peptidase activity & $23 / 145$ & 0.000 & $\mathrm{GO}$ \\
\hline Acute-phase response & $8 / 20$ & 0.000 & $\mathrm{GO}$ \\
\hline Chemotaxis & $10 / 81$ & 0.003 & GO \\
\hline Basement membrane & $10 / 68$ & 0.000 & $\mathrm{GO}$ \\
\hline Cell adhesion & $36 / 545$ & 0.020 & $\mathrm{GO}$ \\
\hline Extracellular space & $47 / 375$ & 0.000 & GO \\
\hline Heparin binding & $13 / 90$ & 0.000 & $\mathrm{GO}$ \\
\hline Neuroactive ligand-receptor interaction & $14 / 173$ & 0.036 & KEGG \\
\hline
\end{tabular}

${ }^{1}$ Numbers of genes among DEG and on the microarray platform. ${ }^{2}$ Yates' corrected chi-square. ${ }^{3}$ Immune related groups and pathways are highlighted with bold.

cells in the target site. Stable up-regulation during 1-5 dpi was observed in a panel of signal transducers: LCK2, protein kinase D3, RAS homologue member G (RhoG), spleen tyrosine kinase (SYK), GRB2-related adaptor protein 2, G protein-coupled receptor kinase 5, RAS guanyl-releasing protein 2, which are known for their important roles in regulating immune cell movement $[19,20]$. Several of these genes have shown preferential expression in salmon peripheral blood leukocytes in previous microarray study [14]; however, their association with specific cell lineages remains unknown. Microarray analyses showed decreased abundance of transcripts for proteins that have a major part in transendothelial migration of leukocytes, including annexin 2, myosin
9 - a non-muscle motor protein, and integrin beta; CD9 and CD63 expressed on leukocyte membranes interact with integrins and proteins of extracellular matrix. Down-regulated CD53 mediates activation of leukocytes and MafB is the myeloid associated differentiation marker. We did not see induction of myeloid-specific genes while a number of events suggested recruitment and activation of lymphoid cells. Increase was observed in a panel of T-cell-specific genes including $\mathrm{T}$-cell receptor alpha (TCR $\alpha)$, serine/threonine-protein phosphatase $2 \mathrm{~B}$, L-plastin, drebrin suggesting preponderance of $\mathrm{T}$ lymphocytes among immune cells that appeared in the target sites (Figure 6A). Up-regulation of TCR $\alpha$ and $\mathrm{CD} 3 \varepsilon$ in the head kidney at $1 \mathrm{dpi}$ and decrease at $5 \mathrm{dpi}$ 


\begin{tabular}{|c|c|c|c|c|c|c|c|c|c|c|c|}
\hline Gene & D1 & D3 & D5 & D10 & D15 & Gene & D1 & D3 & D5 & D10 & D15 \\
\hline Rhamnose-binding lectin WCL1 & 2.07 & 0.42 & 0.82 & 0.09 & 0.61 & Interferon regulatory factor 1 & -0.23 & -1.16 & -0.98 & 0.51 & -0.08 \\
\hline CD209 antigen-like protein D & 1.07 & 0.94 & 0.63 & -0.30 & -0.19 & Gamma-interferon-inducible thiol reductase & -0.58 & -1.28 & -1.06 & 0.30 & 0.29 \\
\hline C-type lectin domain family $4 \mathrm{E}$ & 1.60 & 4.28 & 1.60 & -0.03 & 0.53 & Interferon regulatory factor 2-binding protein 1 & -0.79 & -1.43 & -0.75 & 0.40 & -0.21 \\
\hline Mannose receptor C type 1 & 1.45 & 0.46 & 0.57 & -0.39 & 0.32 & Interferon-gamma receptor alpha chain & -0.75 & -1.29 & -1.14 & 0.31 & 0.05 \\
\hline Mannose receptor, $\mathrm{C}$ type 2 & 3.15 & 4.10 & 2.09 & 0.50 & 0.37 & Interferon-inducible protein Gig2-like & -0.92 & -1.30 & -1.13 & 0.01 & 0.06 \\
\hline Mannose-binding protein $\mathrm{C}$ & -0.58 & -3.09 & -3.34 & 0.25 & 0.29 & Probable ATP-dependent RNA helicase DHX58 & -1.36 & -1.56 & -1.38 & -0.36 & -0.08 \\
\hline Polymeric immunoglobulin receptor & 1.72 & 1.18 & 1.33 & -0.47 & 0.53 & \begin{tabular}{|l|} 
Janus kinase 1 \\
\end{tabular} & -1.62 & -1.03 & -0.64 & -0.56 & -0.03 \\
\hline Complement factor $\mathrm{H} 1$ protein & 2.79 & 2.61 & 2.44 & 0.15 & 1.16 & VHSV-induced protein-10 & -0.91 & -1.51 & -0.77 & -0.61 & -0.15 \\
\hline C4b-binding protein alpha chain & -0.78 & -1.50 & -1.06 & 0.40 & -0.50 & Sacsin & -1.37 & -1.48 & -1.38 & -0.86 & 0.16 \\
\hline CD59 glycoprotein & -0.94 & -1.67 & -1.14 & -0.43 & -0.52 & Interferon-induced protein 44 & -1.05 & -1.62 & -0.74 & -0.79 & -0.55 \\
\hline Complement Clq-like protein 4 & -0.44 & -1.79 & -1.84 & -0.18 & 0.06 & Interferon-induced with tetratricopeptide repeats 5 & -1.49 & -1.06 & -0.78 & -1.16 & 0.04 \\
\hline Complement $\mathrm{Clq}$ subcomponent subunit $\mathrm{B}$ & -1.08 & -1.92 & -1.61 & 0.66 & -0.24 & Interferon regulatory factor 7 & -1.19 & -0.39 & -1.39 & -0.92 & -0.50 \\
\hline Clq-like protein 4 & -2.84 & -0.24 & 0.56 & 5.24 & 3.78 & Interferon-induced protein 44 & -0.90 & -1.35 & -0.93 & -1.07 & -0.78 \\
\hline Prostaglandin E synthase 3 & 1.42 & 0.62 & 0.49 & 0.01 & 0.29 & Inducible nitric oxide synthase & -2.01 & -1.32 & -0.69 & -0.06 & 0.02 \\
\hline Phospholipase A2, group VI isoform b & 1.41 & 1.03 & 1.18 & -0.29 & 0.09 & C-reactive protein & -1.31 & -1.81 & -1.80 & 0.41 & -0.33 \\
\hline C-C chemokine receptor type 3 & 1.77 & 0.93 & 0.90 & -0.22 & 0.13 & Lysozyme g & -1.35 & -1.14 & -1.04 & -0.39 & -0.45 \\
\hline Amyloid beta $\mathrm{A} 4$ protein, isoform a & 2.63 & 1.74 & 2.38 & -0.01 & 1.14 & Cytochrome b558 alpha-subunit & -2.70 & -0.71 & -1.33 & -0.72 & -0.29 \\
\hline SAPS domain family member 3 & 2.37 & 3.37 & 1.07 & -0.21 & 0.14 & Integrin beta-1 & -0.08 & -1.22 & -1.55 & 1.38 & 0.49 \\
\hline Tax1 & 2.01 & 1.90 & 1.19 & 0.15 & 0.11 & Integrin beta- 2 & -1.00 & -1.02 & -1.01 & 1.28 & 0.33 \\
\hline Nuclear factor NF-kappa-B p100 subunit & 1.38 & 0.70 & 0.86 & -0.08 & 0.09 & Matrix metalloproteinase- 9 & -0.31 & -0.95 & -0.72 & 2.19 & 0.47 \\
\hline Tax1 & -1.91 & -1.49 & -1.58 & 0.04 & -0.29 & Collagenase 3 & -0.44 & -0.30 & -0.11 & 2.52 & -0.14 \\
\hline Transcription factor AP-1 & -1.04 & -0.87 & -0.25 & -0.63 & -0.33 & Matrix metalloproteinase-9 & -1.51 & -0.78 & -1.52 & 1.67 & 0.74 \\
\hline Nuclear factor NF-kappa-B p100 subunit & -0.69 & -1.08 & -0.80 & -0.10 & -0.23 & Serum amyloid A-5 protein & -0.95 & -3.33 & -3.59 & 2.88 & 1.68 \\
\hline Transcription factor jun-B & -0.01 & -1.44 & -1.23 & 0.61 & 0.18 & Cathelicidin antimicrobial peptide & -1.62 & -2.16 & -3.25 & 1.84 & 0.26 \\
\hline Galectin-9 & -0.42 & -1.14 & -1.26 & 0.64 & 0.42 & C3a anaphylatoxin chemotactic receptor & -0.58 & -0.05 & -0.04 & 1.42 & 0.57 \\
\hline - & & & & & & 2, & & & & & \\
\hline
\end{tabular}

(Figure 6D) implied rapid recruitment of T-cells from this depot. The nature of these cells remains unknown. No expression changes of CD8 were detected though the microarray platform included probes to alpha and beta chains whose performance was confirmed in studies with viral diseases including cardiomyopathy syndrome (CMS), heart and skeletal muscle inflammation
(HSMI), and the infectious salmon anemia (ISA) (unpublished results). The RT-qPCR analyses found a short-term up-regulation of CD4-1 in skin (Figure 6C). An interesting finding was expression changes of genes that control differentiation of lymphocytes. This was shown by an increase in several genes that regulate early lymphopoiesis, such as kin of IRRE like 3, myeloid/

\begin{tabular}{|c|c|c|c|c|c|c|c|c|c|c|c|}
\hline Gene & D1 & D3 & D5 & D10 & D15 & Gene & D1 & D3 & D5 & D10 & D15 \\
\hline Acute phase serum amyloid A (SAA) & 3.17 & -0.35 & 0.53 & -0.69 & 0.72 & C-C motif chemokine $28-1$ & -0.04 & 0.11 & 0.80 & 1.85 & -0.96 \\
\hline Cathelicidin antimicrobial peptide & 1.88 & -0.13 & 0.70 & -0.54 & 0.83 & C-C motif chemokine $28-2$ & 0.14 & -0.07 & 0.77 & 1.84 & -0.21 \\
\hline Differentially regulated trout protein 1 & 2.54 & 0.89 & 0.40 & -2.17 & -0.70 & $\mathrm{C}-\mathrm{x}-\mathrm{c}$ chemokine receptor type $3 \mathrm{~A}-1$ & 0.17 & 0.59 & 0.45 & 1.23 & 0.51 \\
\hline Jeltraxin precursor & 1.51 & -0.06 & 0.90 & -0.39 & 0.03 & Complement factor $\mathrm{H} 1$ protein & 0.46 & 0.39 & 0.75 & 2.31 & -0.11 \\
\hline Lysozyme C II precursor & 1.40 & -0.11 & 0.20 & -0.76 & 0.75 & Complement factor D precursor & 0.35 & 0.30 & 0.17 & 1.56 & 0.96 \\
\hline Metalloreductase STEAP4-1 & 1.59 & 0.92 & -0.18 & -0.11 & 0.20 & IL-8 receptor & -0.44 & 1.24 & 0.66 & 1.87 & 1.27 \\
\hline Metalloreductase STEAP4-2 & 2.05 & 1.47 & 0.08 & & 0.45 & Interleukin-2 receptor subunit beta & 0.01 & -0.04 & 0.85 & 1.90 & -0.34 \\
\hline Serum amyloid A & 2.42 & -0.91 & 0.49 & -1.70 & 0.25 & Neutrophil cytosolic factor 1 & 0.41 & 1.09 & 0.09 & 1.01 & 1.09 \\
\hline Transferrin & 1.81 & 0.54 & -2.47 & -0.82 & 0.58 & Myeloperoxidase precursor & -0.23 & -0.31 & 0.05 & 1.27 & 0.93 \\
\hline C-X-C motif chemokine 10 precursor & 1.04 & -0.09 & 0.94 & -1.39 & 0.24 & Arachidonate 5-lipoxygenase-activating $\mathrm{p}$ & -0.11 & 0.63 & 0.13 & 1.16 & 0.15 \\
\hline C type lectin receptor $\mathrm{A}$ & 1.29 & 0.91 & 0.23 & -0.67 & 0.51 & Leukotriene A-4 hydrolase & -0.11 & 0.77 & -0.05 & 1.02 & 0.79 \\
\hline TNF decoy receptor & 1.16 & -0.42 & 0.14 & -1.44 & 0.93 & Rhamnose-binding lectin WCL1 & 0.44 & 0.22 & 0.91 & 2.14 & -0.25 \\
\hline Tumor necrosis factor-inducible protein & 1.55 & 0.52 & 0.63 & -1.02 & 0.88 & Matrix metalloproteinase & 0.27 & 1.62 & 0.70 & 1.59 & 1.31 \\
\hline MAP kinase-activated protein kinase 3 & 0.61 & 0.52 & 0.98 & 2.16 & -0.05 & Matrix metalloproteinase- 9 & \begin{tabular}{|l|l|}
-0.30 \\
\end{tabular} & 1.63 & 0.00 & 1.71 & 1.44 \\
\hline Natterin-like protein & -0.09 & 1.13 & -0.14 & 1.63 & 0.02 & Collagenase 3 precursor & -0.27 & 1.64 & 0.21 & 1.70 & 1.72 \\
\hline $\begin{array}{ll}\text { Down }>32 & 32-5.7\end{array}$ & & & & $1.6-$ & & $1.3-1.6$ & $7-32$ & & 520 & & \\
\hline
\end{tabular}




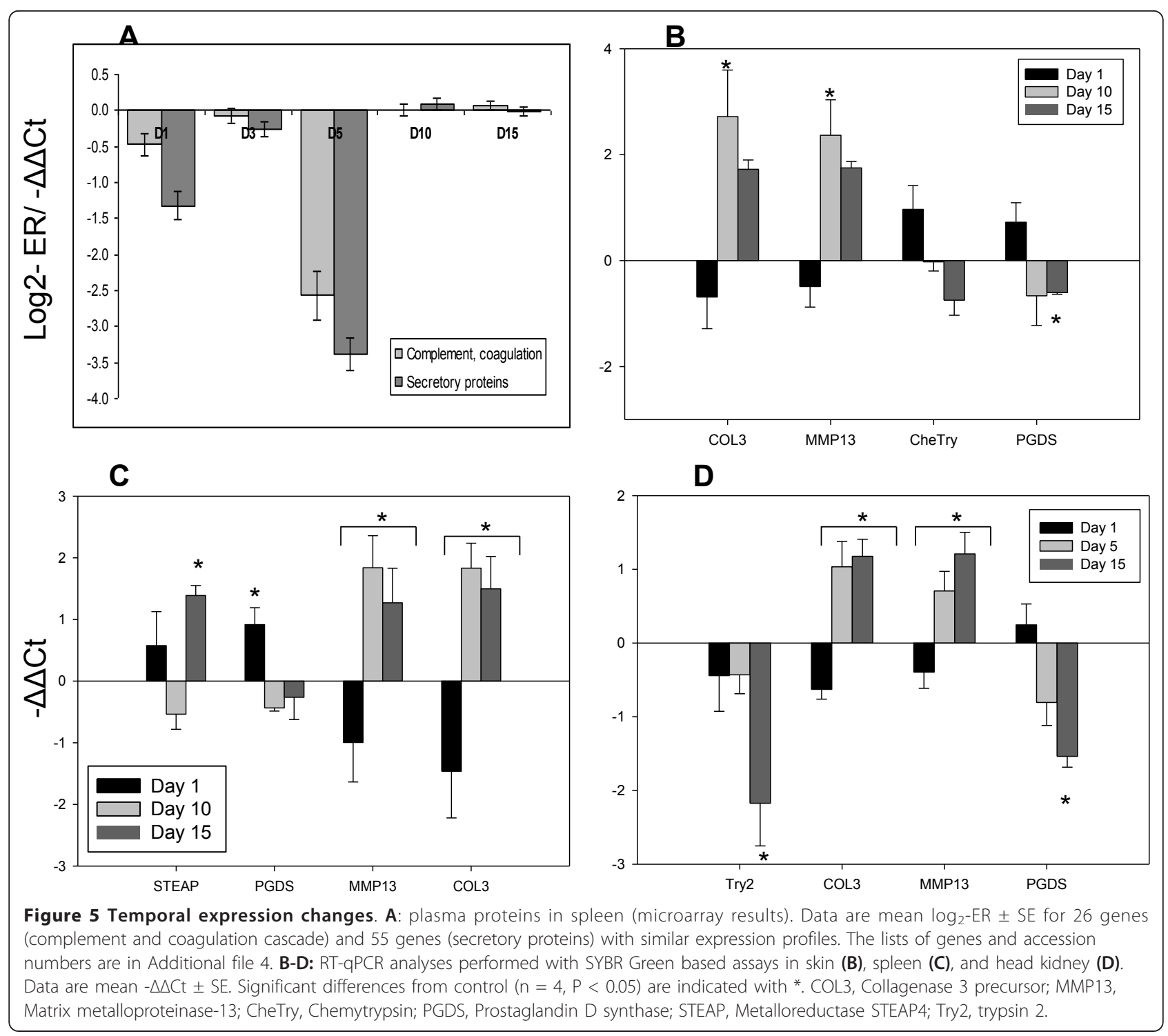

lymphoid or mixed-lineage leukemia, notch 1, Ikaros, growth factor independent (Figure 6A). Translin and translin-associated $\mathrm{X}$ interacting protein 1 are required for somatic recombination of genes encoding immunoglobulins (Ig) and T-cell receptors [21], while BTG3 and IRF4 stimulate their transcription. This may mean that terminal differentiation of T-cells takes place in the infected sites and we came to a similar conclusion in our studies of a viral disease CMS (unpublished data).

We did not find any indications of T-cell mediated immunity in subsequent responses. Down-regulation of MHCI, B2M in skin and head kidney during 1-5, and $15 \mathrm{dpi}$, and MHCII in skin $15 \mathrm{dpi}$ (Figure 6), suggested absence of antigen presentation to T-cells. After $5 \mathrm{dpi}$ the $\mathrm{T}$-cell related genes showed no expression changes in skin. In contrast, there was evidence for the development of B cell mediated immunity. Despite an early regulation in skin of polymeric immunoglobulin receptor (pIgR), a key molecule in transcytosis of Igs (Figure 3), neither microarray nor RT-qPCR analyses showed early regulation of Ig genes in skin. Rapid ( $1 \mathrm{dpi}$ ) up-regulation of IgM and IgT in the head kidney followed with decrease at $5 \mathrm{dpi}$ (additional file 2) suggested recruitment of $B$ cells. However since no increase of B cell-specific transcripts were detected in skin at 1-3 dpi, they probably did not appear in the target site. However, RT-qPCR analyses revealed gradual increase of $\operatorname{IgM}$ and $\operatorname{IgT}$ transcripts from 10 to 15 dpi (Figure 7). Up-regulation of several isoforms of lymphocyte G0/G1 switch protein 2 at 5 dpi (data not shown) probably marked an onset of adaptive immune responses in the spleen. A large panel of Ig transcripts 


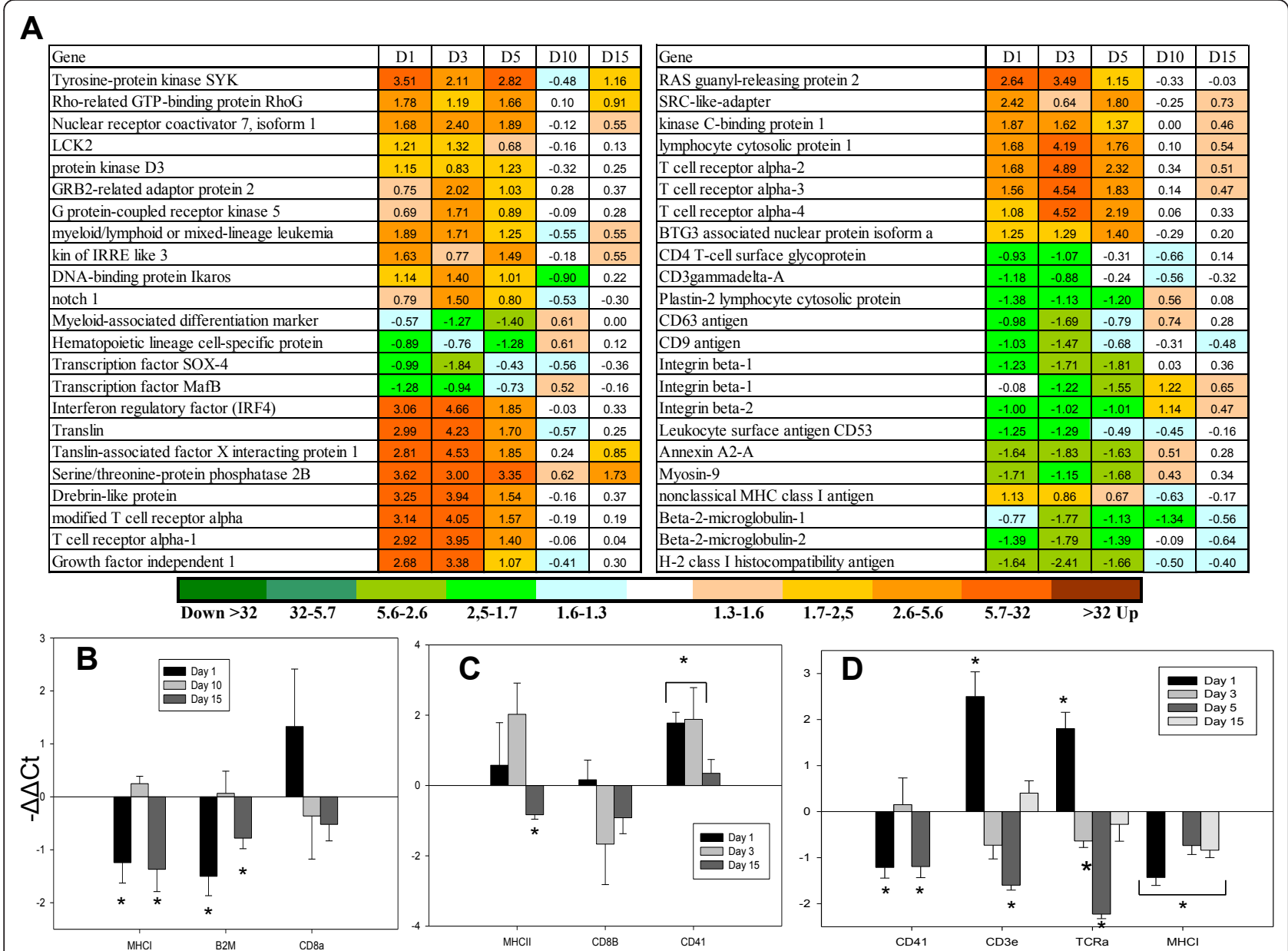

Figure 6 Examples of genes involved in cellular immunity with differential expression in skin and head kidney. A: microarrays in skin, data are mean $\log _{2}-E R(n=4)$. The gene functions are explained in the text. B-D: RT-qPCR analyses of MHC and T-cell markers in skin (B \&C), and in head kidney (D) performed with SYBR Green and TaqMan based assays. Data are mean $-\triangle \triangle C t \pm$ SE. Significant differences from control $(n=4, P<0.05)$ are indicated with *.

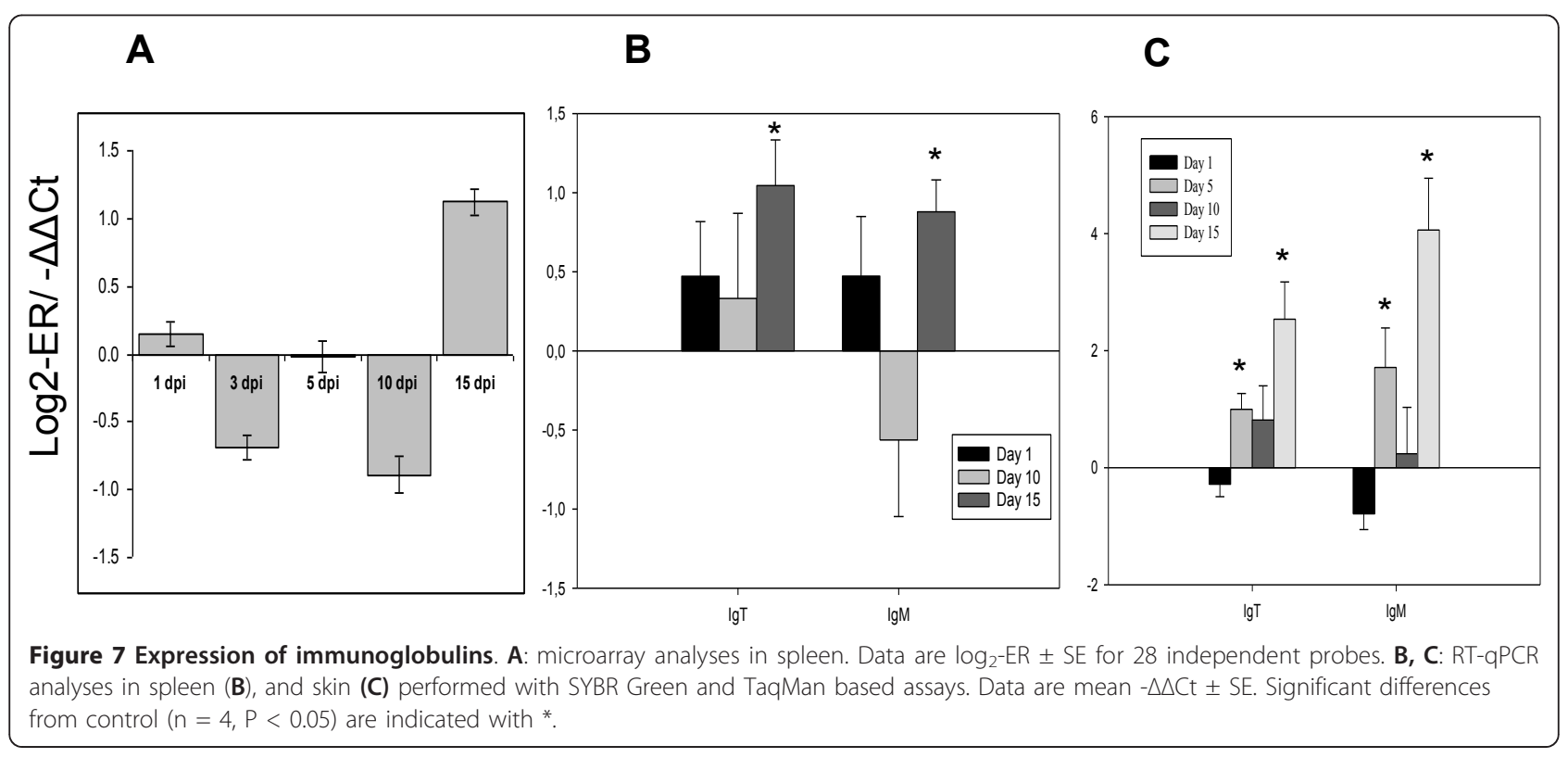


showed decrease at $10 \mathrm{dpi}$ followed with up regulation at $15 \mathrm{dpi}$.

\section{Discussion}

The Atlantic salmon is highly susceptible to $L$. salmonis and the present study was thus designed to identify host responses due to the early infectious stages from 1 to 15 dpi. After settlement, copepodids spend 7 to 11 days (at $9^{\circ} \mathrm{C}$ ) on the host before all have completed the molt and are physically attached to the host by a frontal filament. We focused on the first 15 days after infection and the host responses were related to copepodids (day 1 to 5 ), mixed copepodid and chalimus (day 10) and chalimus (day 15) (Figure 8). We used advantages of multiple

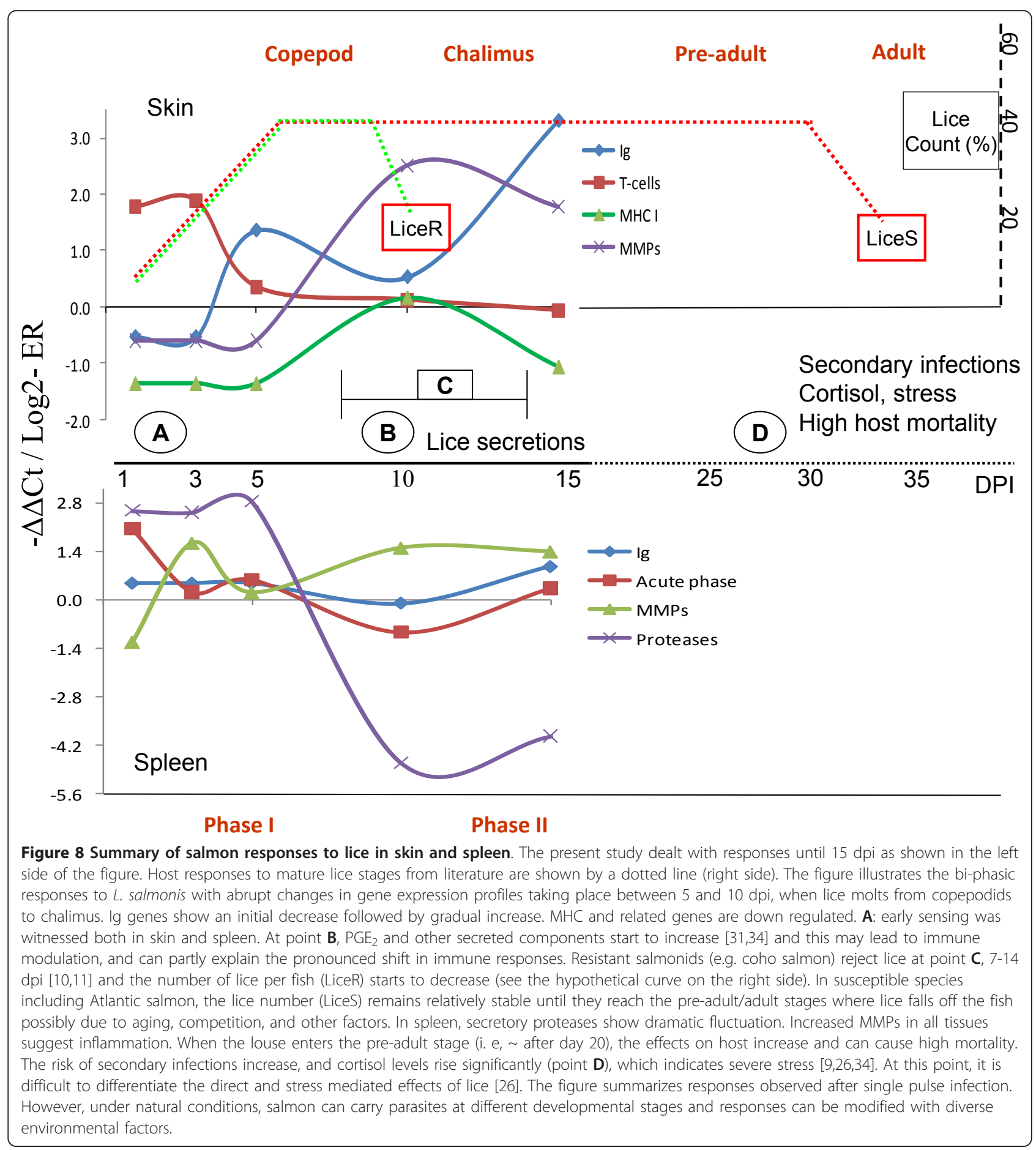


gene expression profiling with a $21 \mathrm{k}$ oligonucleotide microarray, which covers the major fraction of proteincoding genes in Atlantic salmon. Transcriptional responses to salmon louse were analyzed in skin, the first entry point for the parasite, and in the spleen. The latter was selected due to the important role as a lymphoid organ [22] and furthermore, in our previous microarray study [13] we found greater gene expression changes in salmon spleen in comparison with the head kidney, another major immune organ of teleost fish. Our data revealed a strong host response one day post infection with a pronounced switch in gene expression pattern taking place between 5 and $10 \mathrm{dpi}$. This switch corresponds to the period where lice molt from copepodids to chalimus I ending up with a new transcription pattern at day 15 where all surviving parasites have developed into chalimus (Figure 8). In contrast to Pacific salmon, Atlantic salmon show limited tissue response to L. salmonis infections [10]. The reason for this is unknown but a recent study [23] indicates that the Pacific and Atlantic form of L. salmonis may represent two different species and this may account for some of the differences. In addition to immune parameters, differing resistance of salmonids to $L$. salmonis can be related to the structure of skin, composition of mucus, and environmental factors [5,9-12,24].

Little is known about how teleosts respond to parasites in general and to the salmon louse in particular. By using a microarray approach it is possible to screen a large number of markers and to identify both known and novel host responses to the pathogen of interest. Use of genomic tools allowed reconsidering of views based on the studies with limited sets of immune parameters. It was thought that louse do not cause significant effect in Atlantic salmon at early stages [25]. Weak inflammation at the site of attachment was regarded as a plausible explanation of higher susceptibility of Atlantic salmon in comparison with closely related species, such as sockeye and coho salmon (reviewed in [26]). However, transcriptomic analyses did not show low levels of immune responses to lice in Atlantic salmon. Dramatic gene expression changes were seen immediately after infection in the target site (skin) and in the spleen; both local and systemic sensing was rapid and large by scale. Given that most differentially expressed genes are not those that are commonly included in studies of salmon immunity, it would be difficult to detect these changes based on the candidate genes approach. An unexpected finding was involvement of splenic proteases. Dramatic expression changes of a group of genes encoding functionally related proteins imply their important role, which remains completely unknown. Thus, results of transcriptome analyses suggest that low resistance of Atlantic salmon to lice appears to be accounted for by the character of immune response rather than the scale of the response. The results elucidated immune processes that are activated but most likely do not confer substantial protection against the parasite.

High-throughput analyses revealed a bi-phasic response to lice. Modulation of responses by the parasite can be considered as one possible explanation. It is well documented that parasites have the ability to modulate host response to avoid rejection by the host and by this increase survival. For ectoparasites this can be conducted by releasing excreted products to the host surface or the site of feeding. Based on knowledge from other ectoparasites it is likely that $L$. salmonis releases a diversity of secretory/excretory products when it settles on a suitable host. Recently it was shown that horse fly (Tanabus yao) release a wide diversity of molecules when feeding and these molecules where shown to affect a range of biochemical and physiological processes in the host [27]. Salivary gland extracts from ticks suppress lymphocyte proliferation and cytokine response [28]. Parasites such as Leishmania utilize a number of immune avoidance strategies [29], some of which resembling that of tumor cells [30]. Immune suppression by lice has been reported in several publications. Salmon louse releases molecules that affect host response [31] and a few of these have been identified [31,32]. Lice produce PGE2, trypsin-like proteases, and other products that suppress the immune system of Atlantic salmon [33]. Significant reduction of oxidative and phagocytic activities of macrophages [25], and reduced transcription of IL- $1 \beta$ and COX-2 in lice infected salmon has been reported [31,34]. In the present study, a panel of pro-inflammatory cytokines analyzed with RTqPCR (IL1- $\beta$, IL1R1, TNF $\alpha$ and IL-12) did not show significant response to lice. Furthermore, our findings indicated down-regulation of Ag presentation after infection with salmon lice, possibly affecting the conventional T-cell mediated adaptive immune response. Similar down-regulation of genes involved in Ag processing has been documented in Atlantic salmon infected by the protozoan ectoparasite that causes amoebic gill disease (AGD) [35]. This is interesting because L. salmonis is also implicated as a possible risk factor for AGD [36]. In similar host-parasite interaction studies, MHC II gene expression decreased in head kidney and skin after infection of carp with Trypanoplasma borreli [37], and rainbow trout with Gyrodactylus derjavini [38]. Besides, our microarray data shows down-regulation of lysosomal proteases (cathepsins), which process exogenous antigens for presentation by MHC II $[39,40]$.

The character of inflammation changed during the copepodid-chalimus transition as well. Commonly acute and chronic inflammation is associated with cells of 
myeloid origin and lymphocytes, respectively. However, an opposite trend was observed in our study. As shown in Figure 6A and 6C, gene expression changes provided evidence for a rapid recruitment of $\mathrm{T}$-cells in the damaged sites, indicating a short term $\mathrm{T}$-cell mediated response early during infection (1-5 dpi), which completely disappeared after $5 \mathrm{dpi}$. It is worth noting that Atlantic salmon possesses diversified numbers T-cells and receptors [41,42]. Their functional roles remain undetermined, as the true cytokine profile of CD4 response is dependent on interactions between the pathogen and antigen-presenting-cells [43]. In mammals, natural T- cells expressing a conserved TCR $\alpha$-chain can exhibit both $\mathrm{CD}^{+}$and $\mathrm{CD} 4^{-} / 8^{-}$double-negative phenotype [44]. It is possible that in the present study, at least some of the lymphocyte responses could be MHC-independent, possibly belonging to unidentified lineages that are not associated with acquired immunity or immune memory either, as Atlantic salmon used in this study was not immunized previously against lice. These cells could be similar to innate T-like cells which function as natural killer T-cells recognising antigens presented by non-classical MHC molecules [45]. Microarray data showed up-regulation of non-classical MHCI molecules in the skin (Figure 6A). Induction of genes that control early stages of lymphocyte differentiation suggests involvement of precursor cells, which either resided in skin or were delivered with blood. Concurrent down-regulation of several genes in skin that control transendothelial migration indicates the depletion of leukocytes.

A hallmark of transit from acute to chronic inflammation was the systemic increase of MMP9 (gelatinase) and MMP13 (collagenase), which did not show expression changes during the first phase. Earlier we found preferential expression of these genes in salmon leukocytes [14]. The changes of transcript abundance could be due to either MMPs induction in activated resident immune cells (macrophages) or influx of leukocytes. The latter possibility is supported with simultaneous upregulation of integrins and C3a anaphylatoxin chemotactic receptor in skin and neutrophil cytosolic factor in spleen (Figs 3 \& 4). The observed changes can be a consequence of chronic stress and increased production of cortisol. In this respect, it is noteworthy that Fast et al. [34] found no changes of plasma cortisol levels during the first 15 dpi in Atlantic salmon infected with L. salmonis, while its increase at 26-33 dpi was in parallel with the induction of pro-inflammatory mediators (IL-1 $\beta$ and TNF $\alpha$ ). Overall, cortisol has an immune suppressive action. However, a remarkable feature of salmon MMPs is induction with both inflammatory stimuli [46] and stress [47]. Recently we observed up-regulation of MMPs in salmon with cortisol implants (manuscript under preparation). Previously we reported a sustained induction of MMPs as a characteristic feature of lice infection in Atlantic salmon [13]. MMP-9 in carp LPS stimulated leucocytes shows a bi-phasic profile: increase until 48 hours, decline, and another increase at 168 hours, indicating its role both in early inflammation and later stages of tissue remodelling [17].

Vaccines are discussed as a possible measure against salmon louse. Immunization of fish against $L$. salmonis may be facilitated by an improved understanding of the adaptive immune system and molecules involved therein, particularly how the host responds to parasites. One of the limitations with vaccine development could be the limited exposure of louse to blood and thereby serum antibodies (reviewed in [8]), and mucosal immunity might play a major role here as L. salmonis are colonizers of cutaneous mucosa of salmonids. Mucosal epithelial cells serve as an initial barrier and, in addition, they are involved in adaptive immunity by Ag presentation and production of Igs along with complement, lectins, CRP, lysozymes, proteolytic enzymes and other effectors [48-50]. Antibodies at the surface of skin mucus can block ectoparasites from infestation or reduce infestation success [50]. IgT/IgZ is a teleost specific antibody class first discovered in rainbow trout and zebrafish $[51,52]$. In salmon, there are three highly similar IgT sub-variants [53]. A recent study indicated that they might be differentially regulated [54]. IgT is associated with mucosal immunity, similarly to the mammalian IgA [55]. IgT transcription in rainbow trout gut was up-regulated more than 700 fold in fish that survived infection with the parasite Ceratomyxa shasta [55]. This immunoglobulin may coat gut luminal bacteria thus preventing their attachment and invasion of the gut epithelium [55]. While transcript levels of IgT and IgM in mucosal tissues of naïve Atlantic salmon are relatively low [53], we documented up to ten fold increase in skin after infection with $L$. salmonis (Figure 7C). An increase of IgT and IgM transcripts in skin and spleen may indicate an onset of adaptive immune responses at later stages of infection. It is worth mentioning here that microarray data has showed an early up-regulation of pIgR, a key molecule involved in the transport of Igs to mucosal surfaces [55-57]. However, we did not observe an early increase in Ig transcripts at the target site. In addition to transcytosis of Igs, pIgR has an important role in innate immune functions by attaching to host and pathogenic factors, as well as protecting Igs from proteolytic degradation $[57,58]$.

\section{Conclusions}

In this paper we studied gene expression changes in Atlantic salmon skin, spleen and head kidney during the first 15 days post infection by $L$. salmonis, using microarray and RT-qPCR (results are summarised in 
Figure 8 ). The findings clearly indicated early sensing at $1 \mathrm{dpi}$ with induction of genes involved in innate immune reactions, including lectins and enzymes of eicosanoid metabolism in skin and acute phase proteins in spleen. This was followed by regulation of a diverse array of genes including MMPs and immunoglobulins. The responses are bi-phasic with large shift in transcript profiles of many genes during the time window corresponding to the copepod-chalimus transition. Gradual increase of Ig transcripts from 1-15 dpi in skin and spleen, possibly indicated mounting of adaptive immunity, which was supported by the up-regulation of putative lymphocyte G0/G1 switch proteins at $5 \mathrm{dpi}$ in the spleen. The responses, however, did not result in appreciable level of protection, as revealed by the lice load on fish at the end of the study. Down-regulation of the antigen presenting $\mathrm{MHCI}$ and related molecules, and absence of $\mathrm{T}$-cell induction at later stages suggested lack of T-cell dependent acquired immunity. Further biochemical and functional studies of immune mechanisms of IgT at mucosal sites in salmon, in the context of lice infection will greatly contribute to a better understanding of how adaptive immunity is orchestrated in salmon with regard to mucosal defences. Furthermore, the large group of secretory splenic proteases, which show the greatest transcriptional fluctuations (up- and down-regulation), deserve a closer attention.

\section{Methods}

\section{Challenge experiment}

Atlantic salmon in the size range of 100-200 g, which has not previously been in contact with L. salmonis, were placed in two different tanks containing full salinity water (one for control and another for L. salmonis infection), at the Institute of Marine Research (IMR) in Bergen. A hatchery and culturing system that enables laboratory maintenance of salmon louse throughout its life-cycle was developed recently [59]. Salmon louse of LsGulen strain [59] were reared in the hatchery and egg strings were collected and placed into an incubator until they reached the copepodid stage. Atlantic salmon were challenged with L. salmonis (approximately 100 copepodids per fish). Commonly, approximately one third of the copepodids added to a tank are found on fish during the pre-adult/adult stages [59]. Following infection, tissues of skin, spleen, and head kidney were sampled 1, 3, $5 \mathrm{dpi}$ (corresponding to the copepod stage); 10 and $15 \mathrm{dpi}$ (chalimus stage). Control fish were sampled in a similar manner (Figure 9). Immediately after sampling, tissues were stored in liquid nitrogen and then transferred to $-80^{\circ} \mathrm{C}$ freezer. The fish were kept at a temperature of $9 \pm$ $1^{\circ} \mathrm{C}$ during the entire experimental period, and fed with commercial diet once daily. Louse load on each fish was counted at the end of the experiment, $15 \mathrm{dpi}$.

\section{RNA and cDNA preparation}

RNA was isolated using the iPrep ${ }^{\mathrm{TM}} \mathrm{TRIzol}^{\circledR}$ Plus kit (Invitrogen), and purified with RNeasy mini kit (QIAGEN). The quantity and quality of the total RNA was assessed using a NanoDrop Spectrophotometer (NanoDrop Technologies) and an Agilent 2100 Bioanalyzer (Agilent Technologies). Samples with RNA integrity number (RIN) of 8 or higher were accepted for microarray analyses. cDNA was synthesized by reverse transcription of RNA using the $\mathrm{qS}$ cript $^{\mathrm{TM}} \mathrm{cDNA}$ Synthesis Kit (Quanta BioSciences). Total RNA and cDNA were stored at -80 and $-20^{\circ} \mathrm{C}$ respectively until use.

\section{Microarray analyses}

RNA amplification and labelling were performed using Two-Colour Quick Amp Labelling Kit and Gene Expression Hybridization kit (for fragmentation of labeled cRNA) following the manufacturer's instructions for $4 \times$ 44 k microarrays (Agilent Technologies). Nofima Marin's salmon oligonucleotide microarray SIQ3 (GEO GPL10706) was fabricated by Agilent Technologies and annotated with STARS bioinformatic package [14]. The features were assigned to the functional classes (GO) and pathways (KEGG). In addition, custom annotations were implemented based on literature and other public sources. Four biological replicates in each of 5 timepoints per tissue (skin and spleen), which comprise a total of 40 microarrays (one array per sample), were included in the analyses (Figure 9). The input of total RNA used in each reaction was 500 ng. Pooled control samples were prepared by mixing equal RNA concentrations from each individual sample of control fish per each time point. Individual samples of infected fish were labeled with Cyanine 5 (Cy5), while control samples were labeled with Cy3. Following labeling, amplification, purification, and quantification, 825 ng of both the Cy5labeled test cRNA samples and Cy3-labelled control samples were mixed and hybridized (competitively) to the arrays (Figure 9). Over night hybridization (17hours, $65^{\circ} \mathrm{C}$, and rotation speed of $10 \mathrm{rpm}$ ) was performed in hybridization oven (Agilent Technologies). After hybridization, arrays were washed with Gene Expression Wash Buffers 1 and 2 and scanned with a GenePix 4100A (Molecular Devices, Sunnyvale, CA, USA). GenePix Pro 6.0 was used for spot to grid alignment, feature extraction and quantification. Assessment of spot quality was done with aid of GenePix. After filtration of flagged low quality spots, Lowess normalization of $\log _{2}$-expression ratios (ER) was performed. The differentially expressed genes (DEG) were selected by criteria: $\log _{2} E R>|0.8|$ and $p<0.01$, (sample t-test, null hypothesis $\log _{2} \mathrm{ER}=0$ ) in at least one time-point. The microarray data were submitted to GEO, GSE26981 (skin) and GSE26984 (spleen). 


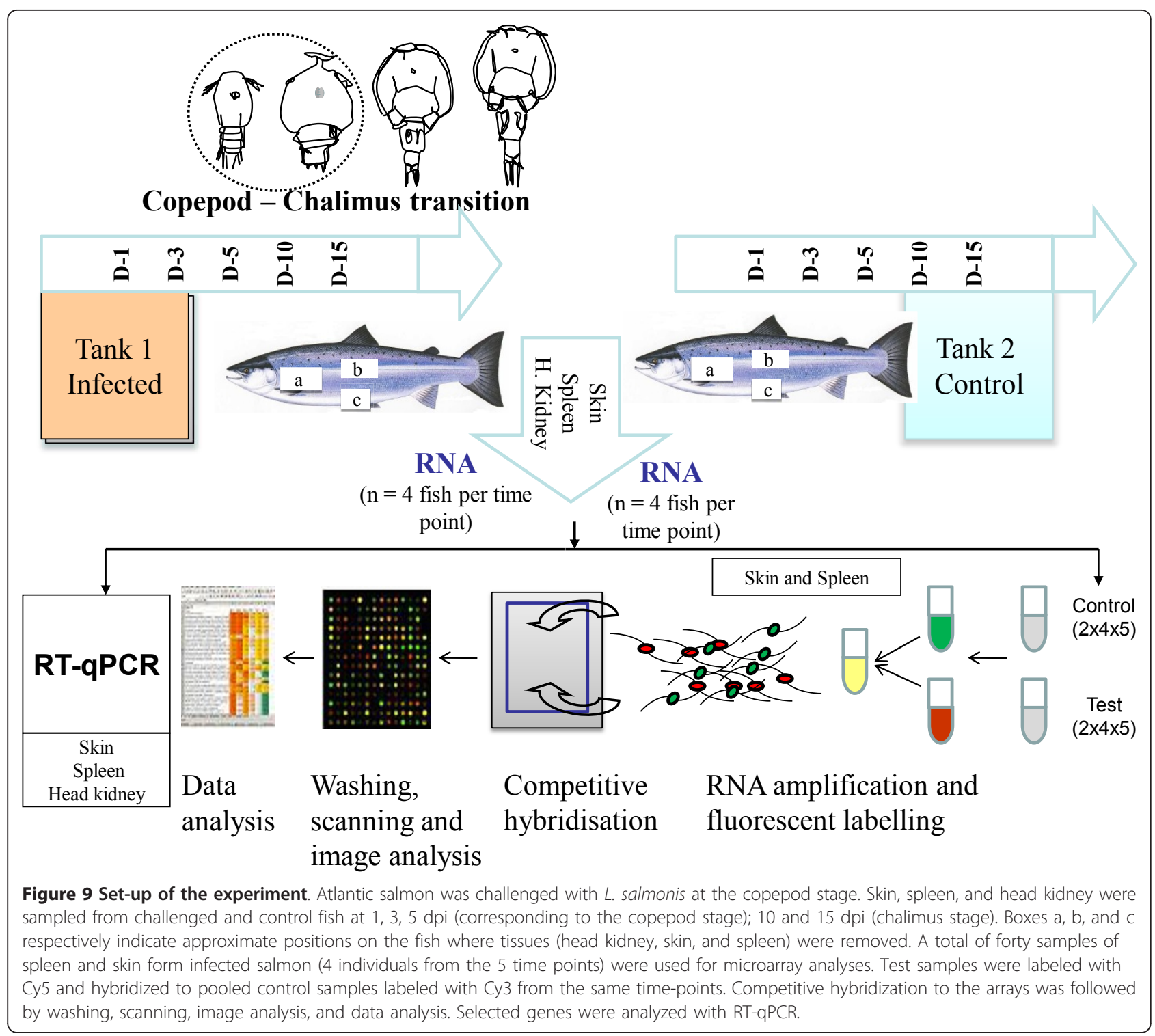

\section{RT-qPCR}

Eighteen differentially expressed genes from the microarray experiment, covering the entire dynamic range of expression, were selected for verification with RT-qPCR. Preference was given to immune genes and to genes with unknown roles that showed strong responses to the parasite. In addition, T-cell markers, immunoglobulins (Ig), and genes of antigen presentation, and proinflammatory cytokines were included. RT-qPCR analyses were carried out with skin, spleen and head kidney. TaqMan ${ }^{\circledR}$ probe, and SYBR Green based RealTime PCR assays were designed using Primer express 3.0 (Applied Biosystems), and Beacon Designer 7.8 (PREMIER Biosoft, USA) respectively (Table 2). When possible, primers or probes were designed to span between two exons. Fast SYBR ${ }^{\circledR}$ Green Master Mix based PCR was performed using 7500 Fast Real-Time PCR System (Applied Biosystems). The PCR reaction mix contained $5 \mu$ l of Fast SYBR ${ }^{\circledR}$ Green Master Mix $(2 \times), 500 \mathrm{nM}$ of each primer, and $2 \mu \mathrm{l}$ of cDNA in a final volume of $10 \mu \mathrm{l}$. Thermal cycling was carried out according to the manufacturers protocol (Applied Biosystems) as follows: enzyme activation at $95^{\circ} \mathrm{C}$ for $20 \mathrm{sec}$, followed by 40 cycles of denaturation $\left(95^{\circ} \mathrm{C}\right.$ for $3 \mathrm{sec})$, and annealing/extension $\left(60^{\circ} \mathrm{C}\right.$ for $\left.30 \mathrm{sec}\right)$. In addition, Taqman probe based quantitative PCR was performed on a few selected genes using the 7500 Fast Real-Time PCR System (Applied Biosystems), and quantification of mRNA was performed in a single step assay (both RT and PCR steps carried out in the same tube) 
Table 2 Primer/ probe list

\begin{tabular}{|c|c|c|c|c|c|c|}
\hline $\begin{array}{l}. \\
\mathrm{N}\end{array}$ & Sequence Definition & Code & & Primer/ probe $\left(5^{\prime}-3^{\prime}\right)$ & $\begin{array}{r}\text { Product } \\
\text { length }\end{array}$ & $\begin{array}{r}\text { GenBank Accession } \\
(\mathrm{GI}) \\
\end{array}$ \\
\hline \multirow[t]{2}{*}{1.} & Apoptosis regulator $\mathrm{Bcl}-\mathrm{X}$ & Apo & Fwd & TACTAAGTGTTGCCGTTGA & 109 & 209734267 \\
\hline & & & Rev & TAATCCAATCTGTGTCATTCTG & & \\
\hline \multirow[t]{2}{*}{2.} & Beta-2-microglobulin precursor & B2M & Fwd & CACAGACAGACACAGACA & 102 & 221220497 \\
\hline & & & Rev & CAACGATTGACAGAATAGACTT & & \\
\hline \multirow[t]{2}{*}{3.} & Carboxypeptidase A1 precursor & CarPep & Fwd & AGCATACCAAGGACAACAC & 75 & 209732661 \\
\hline & & & Rev & TACAACAGTACAATGACACAGT & & \\
\hline \multirow[t]{2}{*}{4.} & Chymotrypsin B & ChyTry & Fwd & CTGTCCATACTGTATATTGCTAT & 111 & 209734305 \\
\hline & & & Rev & GCTATAATGCTTAGGTGTTGTA & & \\
\hline \multirow[t]{2}{*}{5.} & Collagenase 3 precursor & COL3 & Fwd & ATCTGTGCTTACTACTAATCAAC & 81 & 209156091 \\
\hline & & & Rev & GGGCTTCATCTTCTITACTG & & \\
\hline \multirow[t]{2}{*}{6.} & Complement C1q subcomponent subunit B & $\mathrm{C} 1 \mathrm{qB}$ & Fwd & CTGTCTGTCGTTGTCTTC & 89 & 223649475 \\
\hline & & & Rev & ATGGTCTGTTGGTCTGTA & & \\
\hline \multirow[t]{2}{*}{7.} & Elastase-1 & Ela & Fwd & ACCGTCAACAAAGTCTTCA & 75 & S31963336 \\
\hline & & Rev & & CAGCAGAGCGATGTCATA & & \\
\hline \multirow[t]{2}{*}{8.} & Fish virus induced TRIM protein & TRIM & Fwd & GCATGGCACAATAATAACT & 75 & S35697379 \\
\hline & & & Rev & GTCCAGATACACTCCTAC & & \\
\hline \multirow[t]{2}{*}{9.} & Trypsin-2 & Try2 & Fwd & CAGTTGTCGGTTGAGATG & 81 & S18845530 \\
\hline & & & Rev & CAAGATGTGCCAGATAGC & & \\
\hline \multirow[t]{2}{*}{10} & Trypsin-3 & Try3 & Fwd & CATTATTCTTCTCGCTCTG & 81 & S31964271 \\
\hline & & & Rev & TCATACCCTCCAACAATC & & \\
\hline \multirow[t]{2}{*}{11} & Tumor necrosis factor alpha & TNF $\alpha$ & Fwd & ACAAAGAGGGCCAGGGATTC & 100 & 126507266 \\
\hline & & & Rev & GAGGCCTGGCTGTAGACGAA & & \\
\hline \multirow[t]{2}{*}{12} & Interleukin-1 receptor-like protein & IL1R1 & Fwd & AGCAGGATGTCCTCGGTCTA & 202 & 185136290 \\
\hline & & & Rev & TGGGTAGCGGTGTAGTTCC & & \\
\hline \multirow[t]{2}{*}{13} & Interleukin-1 beta & $\operatorname{IL} 1 \beta$ & Fwd & ACCGAGTTCAAGGACAAGGA & 196 & 186288127 \\
\hline & & & Rev & GCAGCTCCATAGCCTCACTC & & \\
\hline \multirow[t]{2}{*}{14} & Gamma-interferon-inducible lysosomal thiol & GIILTR & Fwd & CTATGTGCCTTGGATTGT & 79 & 209732609 \\
\hline & & & Rev & CAGAGTGAAGAGTGAAGAC & & \\
\hline \multirow[t]{2}{*}{15} & HSP70_ONCMY Heat shock cognate 70 kDa & HSP70 & Fwd & TCACTAGAGTCCTATGCT & 85 & CL7Contig1 \\
\hline & & & Rev & TTGTCTTGTCCTCATCAC & & \\
\hline \multirow[t]{2}{*}{16} & $\begin{array}{l}\text { Lipopolysaccharide-induced TNF-a factor } \\
\text { homolog }\end{array}$ & $\begin{array}{l}\text { LPSi- } \\
\text { TNF } \alpha\end{array}$ & Fwd & CAATTCCTTCGACCTCAT & 85 & 209734201 \\
\hline & & & Rev & GCTCTTCTCCATACTGTC & & \\
\hline \multirow[t]{2}{*}{17} & Metalloreductase STEAP4 & STEAP4 & Fwd & СTCCAACTCTGAAGACTATT & 103 & S48396453 \\
\hline & & & Rev & GAGCACTGTCAATCAATG & & \\
\hline \multirow[t]{2}{*}{18} & Myosin, heavy polypeptide 9 , non-muscle & Myo & Fwd & GCAGTTGAGACTCTACAGTGGAA & 75 & CB498954 \\
\hline & & & Rev & ACAGCGTGTTGAGTGTGGTT & & \\
\hline \multirow[t]{2}{*}{19} & Programmed cell death protein 2 & PCDP & Fwd & GCATAGACAGCCACAATC & 81 & 209735097 \\
\hline & & & Rev & GAGCGTAACAACCTGAAG & & \\
\hline \multirow[t]{2}{*}{20} & Prostaglandin E synthase 3 & PGES & Fwd & TCCAGCCAATGTCTTAGT & 99 & 223672934 \\
\hline & & & Rev & AAGCACGGTATAACTGAAC & & \\
\hline \multirow[t]{2}{*}{21} & P-selectin precursor & P-sel & Fwd & CTGGTGATTCTATTGATGAC & 86 & 209154193 \\
\hline & & Rev & & TTGACGCTGTAGTTGTAT & & \\
\hline 22 & $\operatorname{CD} 8 \alpha$ & $\operatorname{CD} 8 \alpha$ & Fwd & CGTCTACAGCTGTGCATCAATCAA & 118 & 185135177 \\
\hline & & & Rev & GGCTGTGGTCATTGGTGTAGTC & & \\
\hline 23 & Interleukin-12 & $\mid \mathrm{L}-12$ & Fwd & TCTACCTACACGACATTGTCCAGCC & 62 & 209736091 \\
\hline & & & Rev & ATCCATCACCTGGCACTTCATCC & & \\
\hline 24 & Prostaglandin D synthase & PGDS & Fwd & ATCCCAGGCCGCTTCAC & 59 & 304376917 \\
\hline & & & Rev & ACACGCATGTCATTTTCATTGTT & & \\
\hline
\end{tabular}


Table 2 Primer/ probe list (Continued)

\begin{tabular}{|c|c|c|c|c|c|c|}
\hline & & & Probe & TTCACCAGCCAGCGTT & & \\
\hline \multirow[t]{3}{*}{25} & Matrix metalloproteinase-13 & MMP13 & Fwd & GCCAGCGGAGCAGGAA & 56 & 213514499 \\
\hline & & & Rev & AGTCACCTGGAGGCCAAAGA & & \\
\hline & & & Probe & TCAGCGAGATGCAAAG & & \\
\hline \multirow[t]{3}{*}{26} & T-cell receptor alpha & TCR $\alpha$ & Fwd & GACAGCTACTACAGCCAGGTT & & 209736003 \\
\hline & & & Rev & CAGAATGGTCAGGGATAGGAAGTT & & \\
\hline & & & Probe & ACACAGATGCAAAGATC & & \\
\hline \multirow[t]{3}{*}{27} & $\mathrm{CD} 3 \varepsilon$ & $\mathrm{CD} 3 \varepsilon$ & Fwd & TCAGGGCTCGGAAGAAGTCT & 68 & 185135943 \\
\hline & & & Rev & GCCACGGCCTGCTGA & & \\
\hline & & & Probe & CCAAAAACCCACTTCCC & & \\
\hline \multirow[t]{3}{*}{28} & CD4-like protein, variant 1 & CD4-1 & Fwd & GAATCTGCCGCTGCAAAGAC & 75 & 185135736 \\
\hline & & & Rev & AGGGATTCCGGTCTGTATGATATCT & & \\
\hline & & & Probe & CCCAAACCAAAAGGATTC & & \\
\hline \multirow[t]{3}{*}{29} & $\mathrm{CD} 8 \beta$ & $\mathrm{CD} 8 \beta$ & Fwd & GGAGGCCAGGAGTTCTTCTC & 70 & 185135192 \\
\hline & & & Rev & GGCTTGGGCTTCGTGACA & & \\
\hline & & & Probe & ACCCGGAGAAACTC & & \\
\hline \multirow[t]{3}{*}{30} & MHC class I antigen & $M H C-I$ & Fwd & CAACGCCACAGGCAGTCA & 64 & 25573077 \\
\hline & & & Rev & CGGTACTCATTCTGAGCTGTGTTAC & & \\
\hline & & & Probe & CACCAAACTCAAGTGGG & & \\
\hline \multirow[t]{3}{*}{31} & MHC class II antigen & $\mathrm{MHC}-\mathrm{II}$ & Fwd & CTCACTGAGCCCATGGTGTAT & 117 & 223672978 \\
\hline & & & Rev & GAGTCCTGCCAAGGCTAAGATG & & \\
\hline & & & Probe & CTGGGACCCGTCCCTG & & \\
\hline \multirow[t]{3}{*}{32} & Immunoglobulin mu & $\lg M$ & Fwd & TGAGGAGAACTGTGGGCTACACT & 69 & 2182101 \\
\hline & & & Rev & TGTTAATGACCACTGAATGTGCAT & & \\
\hline & & & Probe & CATCAGATGCAGGTCC & & \\
\hline \multirow[t]{3}{*}{33} & Immunoglobulin tau & $\lg T$ & Fwd & CAACACTGACTGGAACAACAAGGT & 97 & 260766539 \\
\hline & & & Rev & CGTCAGCGGTTCTGTITTGGA & & \\
\hline & & & Probe & AGTACAGCTGTGTGGTGCA & & \\
\hline \multirow[t]{3}{*}{34} & Elongation factor $1 \mathrm{~A}$ & EF1A & Fwd & CCCCTCCAGGACGTITACAAA & 57 & 224587629 \\
\hline & & & Rev & CACACGGCCCACAGGTACA & & \\
\hline & & & Probe & ATCGGTGGTATTGGAAC & & \\
\hline
\end{tabular}

according to the Verso ${ }^{\mathrm{TM}}$ 1-step QRT-PCR low ROX kit (Thermo Scientific). PCR reaction mix containing 1-step qPCR low ROX mix $(2 \times)$, enzyme mix, RT enhancer, $900 \mathrm{nM}$ of each primer, $200 \mathrm{nM}$ of TaqMan probe was mixed with $2 \mu \mathrm{l}$ (50-100 ng) of RNA in a final volume of $12.5 \mu \mathrm{l}$. This is followed by thermal cycling steps of cDNA synthesis at $50^{\circ} \mathrm{C}$ for $15 \mathrm{~min}$, an enzyme activation step of $95^{\circ} \mathrm{C}$ for $15 \mathrm{~min}$, and 45 cycles of $95^{\circ} \mathrm{C}$ for $15 \mathrm{sec}$ (denaturation) and $60^{\circ} \mathrm{C}$ for $60 \mathrm{sec}$ (annealing/ extension). All samples were run in duplicates (or triplicates) with non-template controls and non-reverse transcription controls on the same plate. Amplification of genomic DNA was checked by a melting curve analysis, which resulted in a single peak, indicating single product amplification. Elongation factor 1 alpha (EF1A) was used as an internal reference gene, as it has been shown to be the best reference gene for RTqPCR studies in Atlantic salmon tissues [60]. We also have recent experience with samples similar to those analysed in this study and EF1A has shown an appropriate stability [53]. This transcript has also been represented in the microarray and did not show response to lice. To calculate $\Delta \mathrm{Ct}$, the respective reference $C t$ values were subtracted from target $C t$ values of the control and test samples; and $-\Delta \Delta C \mathrm{t}$ was calculated as: $-\Delta \Delta C t=-\left(\Delta C t_{\text {Test }}-\Delta C t_{\text {Control }}\right)$. PCR efficiencies were in acceptable range (Additional file 2). Statistical analysis of the RT-qPCR data was done using Microsoft excel and SigmaPlot 11.0. The data were presented as mean $-\Delta \Delta \mathrm{Ct} \pm \mathrm{SE}$. Differences between control and test at each sampling point were assessed with Student's t-test.

\section{Additional material}

Additional file 1: Differentially expressed genes, complete microarray results.

Additional file 2: Complete RT-qPCR results and PCR efficiencies. Additional file 3: Proteases with differential expression in spleen, microarray results. 
Additional file 4: Secretory proteins, components of complement and coagulation cascade differential expression in spleen, microarray results.

\section{Acknowledgements}

This study was supported with a grant from the functional genomics (FUGE) platform of the Research Council of Norway.

\section{Author details}

${ }^{1}$ Department of Biology, University of Bergen, Thormølhensgate 55, N-5020 Bergen, Norway. ${ }^{2}$ Nofima, Norwegian Institute of Food, Fisheries and Aquaculture Research, P.O. Box 5010, Ås NO-1430, Norway. ${ }^{3}$ Sechenov Institute of Evolutionary Physiology and Biochemistry, M. Toreza av. 44, St Petersburg, 194223, Russia.

\section{Authors' contributions}

TMT contributed to the overall experimental design, conducted the challenge test, the RT-qPCR analysis, performed the microarray experiment, involved in data analysis, drafted and wrote the manuscript. AK analysed the microarray data, drafted and wrote the manuscript. SS performed the microarray experiment and contributed to the overall manuscript. SA developed computer programs and database for management of microarray results and data mining. $\mathrm{IH}$ designed the study and contributed to the overall manuscript. FN designed the study, was involved in the challenge experiment, and contributed to the overall manuscript. All authors read and approved the final manuscript.

\section{Competing interests}

The authors declare that they have no competing interests.

Received: 23 November 2010 Accepted: 7 March 2011

Published: 7 March 2011

\section{References}

1. Johnson SC, Albright LJ: The developmental stages of Lepeophtheirus salmonis (Krøyer, 1837) (Copepoda: Caligidae). Can J Zool 1991, 69:929-950.

2. Grimnes A, Jakobsen PJ: The physiological effects of salmon lice infection on post-smolt of Atlantic salmon. J Fish Biol 1996, 48:1179-1194.

3. Jones S, Kim E, Bennett W: Early development of resistance to the salmon louse, Lepeophtheirus salmonis (Kroyer), in juvenile pink salmon, Oncorhynchus gorbuscha (Walbaum). J Fish Dis 2008, 31:591-600.

4. Costello MJ: How sea lice from salmon farms may cause wild salmonid declines in Europe and North America and be a threat to fishes elsewhere. Proceedings of the Royal Society B-Biological Sciences 2009, 276:3385-3394.

5. Costello MJ: Ecology of sea lice parasitic on farmed and wild fish. Trends Parasitol 2006, 22:475-483.

6. Gustafson L, Ellis S, Robinson T, Marenghi F, Endris R: Efficacy of emamectin benzoate against sea lice infestations of Atlantic salmon, Salmo salar L.: evaluation in the absence of an untreated contemporary control. J Fish Dis 2006, 29:621-627.

7. Alvarez-Pellitero P: Fish immunity and parasite infections: from innate immunity to immunoprophylactic prospects. Vet Immunol Immunopathol 2008, 126:171-198.

8. Raynard RS, Bricknell IR, Billingsley PF, Nisbet AJ, Vigneau A, Sommerville C: Development of vaccines against sea lice. Pest Manag Sci 2002, 58:569-575.

9. Tully O, Nolan DT: A review of the population biology and host-parasite interactions of the sea louse Lepeophtheirus salmonis (Copepoda: Caligidae). Parasitology 2002, 124(Suppl):S165-182.

10. Fast MD, Ross NW, Mustafa ASims DE, Johnson SC, Conboy GA, Speare DJ, Johnson G, Burka JF: Susceptibility of rainbow trout Oncorhynchus mykiss, Atlantic salmon Salmo salar and coho salmon Oncorhynchus kisutch to experimental infection with sea lice Lepeophtheirus salmonis. Dis Aquat Organ 2002, 52:57-68.

11. Johnson SC, Albright LJ: Comparative Susceptibility and Histopathology of the Response of Naive Atlantic, Chinook and Coho Salmon to
Experimental-Infection with Lepeophtheirus-Salmonis (Copepoda, Caligidae). Dis Aquat Organ 1992, 14:179-193.

12. Fast MD, Sims DE, Burka JF, Mustafa A, Ross NW: Skin morphology and humoral non-specific defence parameters of mucus and plasma in rainbow trout, coho and Atlantic salmon. Comp Biochem Physiol A Mol Integr Physiol 2002, 132:645-657.

13. Skugor S, Glover KA, Nilsen F, Krasnov A: Local and systemic gene expression responses of Atlantic salmon (Salmo salar L.) to infection with the salmon louse (Lepeophtheirus salmonis). BMC Genomics 2008, 9:498.

14. Krasnov A, Timmerhaus G, Afanasyev S, Jorgensen SM: Development and assessment of oligonucleotide microarrays for Atlantic salmon (Salmo salar L.). Comp Biochem Physiol Part D Genomics Proteomics 2011, 6:31-38.

15. Arce I, Martinez-Munoz L, Roda-Navarro P, Fernandez-Ruiz E: The human Ctype lectin CLECSF8 is a novel monocyte/macrophage endocytic receptor. Eur J Immunol 2004, 34:210-220.

16. Bayne CJ, Gerwick L, Fujiki K, Nakao M, Yano T: Immune-relevant (including acute phase) genes identified in the livers of rainbow trout, Oncorhynchus mykiss, by means of suppression subtractive hybridization. Dev Comp Immunol 2001, 25:205-217.

17. Chadzinska M, Baginski P, Kolaczkowska E, Savelkoul HF, Kemenade BM: Expression profiles of matrix metalloproteinase 9 in teleost fish provide evidence for its active role in initiation and resolution of inflammation. Immunology 2008, 125:601-610.

18. Hasebe T, Kajita M, Fujimoto K, Yaoita Y, Ishizuya-Oka A: Expression profiles of the duplicated matrix metalloproteinase- 9 genes suggest their different roles in apoptosis of larval intestinal epithelial cells during Xenopus laevis metamorphosis. Dev Dyn 2007, 236:2338-2345.

19. Maghazachi AA: Insights into seven and single transmembrane-spanning domain receptors and their signaling pathways in human natural killer cells. Pharmacol Rev 2005, 57:339-357.

20. Salmond RJ, Filby A, Qureshi I, Caserta S, Zamoyska R: T-cell receptor proximal signaling via the Src-family kinases, Lck and Fyn, influences Tcell activation, differentiation, and tolerance. Immunol Rev 2009, 228:9-22.

21. Aoki K, Inazawa J, Takahashi T, Nakahara K, Kasai M: Genomic structure and chromosomal localization of the gene encoding translin, a recombination hotspot binding protein. Genomics 1997, 43:237-241.

22. Whyte SK: The innate immune response of finfish-a review of current knowledge. Fish Shellfish Immunol 2007, 23:1127-1151.

23. Yazawa R, Yasuike M, Leong J, von Schalburg KR, Cooper GA, BeetzSargent M, Robb A, Davidson WS, Jones SR, Koop BF: EST and mitochondrial DNA sequences support a distinct Pacific form of salmon louse, Lepeophtheirus salmonis. Mar Biotechnol (NY) 2008, 10:741-749.

24. Bricknell IR, Dalesman SJ, O'Shea B, Pert CC, Luntz AJ: Effect of environmental salinity on sea lice Lepeophtheirus salmonis settlement success. Dis Aquat Organ 2006, 71:201-212.

25. Mustafa A, MacWilliams C, Fernandez N, Matchett K, Conboy GA, Burka JF: Effects of sea lice (Lepeophtheirus salmonis Kroyer, 1837) infestation on macrophage functions in Atlantic salmon (Salmo salar L.). Fish Shellfish Immunol 2000, 10:47-59.

26. Wagner GN, Fast MD, Johnson SC: Physiology and immunology of Lepeophtheirus salmonis infections of salmonids. Trends Parasitol 2008, 24:176-183.

27. Xu X, Yang H, Ma D, Wu J, Wang Y, Song Y, Wang X, Lu Y, Yang J, Lai R: Toward an understanding of the molecular mechanism for successfu blood feeding by coupling proteomics analysis with pharmacological testing of horsefly salivary glands. Mol Cell Proteomics 2008, 7:582-590.

28. Ramachandra RN, Wikel SK: Modulation of host-immune responses by ticks (Acari: Ixodidae): effect of salivary gland extracts on host macrophages and lymphocyte cytokine production. J Med Entomol 1992, 29:818-826.

29. Bogdan C, Rollinghoff M: The immune response to Leishmania: mechanisms of parasite control and evasion. Int J Parasitol 1998, 28:121-134.

30. Ouaissi A, Ouaissi M: Molecular basis of Trypanosoma cruzi and Leishmania interaction with their host(s): exploitation of immune and defense mechanisms by the parasite leading to persistence and chronicity, features reminiscent of immune system evasion strategies in cancer diseases. Arch Immunol Ther Exp (Warsz) 2005, 53:102-114.

31. Fast MD, Johnson SC, Eddy TD, Pinto D, Ross NW: Lepeophtheirus salmonis secretory/excretory products and their effects on Atlantic salmon immune gene regulation. Parasite Immunol 2007, 29:179-189. 
32. Fast MD, Burka JF, Johnson SC, Ross NW: Enzymes released from Lepeophtheirus salmonis in response to mucus from different salmonids. J Parasitol 2003, 89:7-13.

33. Firth KJ, Johnson SC, Ross NW: Characterization of proteases in the skin mucus of Atlantic salmon (Salmo salar) infected with the salmon louse (Lepeophtheirus salmonis) and in whole-body louse homogenate. J Parasitol 2000, 86:1199-1205.

34. Fast MD, Muise DM, Easy RE, Ross NW, Johnson SC: The effects of Lepeophtheirus salmonis infections on the stress response and immunological status of Atlantic salmon (Salmo salar). Fish Shellfish Immunol 2006, 21:228-241.

35. Young ND, Cooper GA, Nowak BF, Koop BF, Morrison RN: Coordinated down-regulation of the antigen processing machinery in the gills of amoebic gill disease-affected Atlantic salmon (Salmo salar L.). Mol Immunol 2008, 45:2581-2597.

36. Nowak BF, Bryan J, Jones SRM: Do salmon lice, Lepeophtheirus salmonis, have a role in the epidemiology of amoebic gill disease caused by Neoparamoeba perurans? J Fish Dis 2010, 33:683-687.

37. Saeij JP, de Vries BJ, Wiegertjes GF: The immune response of carp to Trypanoplasma borreli: kinetics of immune gene expression and polyclonal lymphocyte activation. Dev Comp Immunol 2003, 27:859-874.

38. Lindenstrom T, Secombes CJ, Buchmann K: Expression of immune response genes in rainbow trout skin induced by Gyrodactylus derjavini infections. Vet Immunol Immunopathol 2004, 97:137-148.

39. Riese RJ, Chapman HA: Cathepsins and compartmentalization in antigen presentation. Curr Opin Immunol 2000, 12:107-113.

40. Lennon-Duménil A-M, Bakker AH, Wolf-Bryant $P$, Ploegh HL, LagaudrièreGesbert C: A closer look at proteolysis and MHC-class-II-restricted antigen presentation. Curr Opin Immunol 2002, 14:15-21.

41. Collet B, Collins C: Comparative gene expression profile in two Atlantic salmon cell lines TO and SHK-1. Vet Immunol Immunopathol 2009, 130:92-95.

42. Yazawa R, Cooper GA, Hunt P, Beetz-Sargent M, Robb A, Conrad M, McKinnel L, So S, Jantzen S, Phillips RB, et al: Striking antigen recognition diversity in the Atlantic salmon T-cell receptor alpha/delta locus. Dev Comp Immunol 2008, 32:204-212.

43. Jankovic D, Sher A, Yap G: Th1/Th2 effector choice in parasitic infection: decision making by committee. Curr Opin Immunol 2001, 13:403-409.

44. Joyce S: Natural T cells: cranking up the immune system by prompt cytokine secretion. Proc Natl Acad Sci USA 2000, 97:6933-6935.

45. Medzhitov R: Recognition of microorganisms and activation of the immune response. Nature 2007, 449:819-826.

46. MacKenzie S, Iliev D, Liarte C, Koskinen H, Planas JV, Goetz FW, Molsa H, Krasnov A, Tort L: Transcriptional analysis of LPS-stimulated activation of trout (Oncorhynchus mykiss) monocyte/macrophage cells in primary culture treated with cortisol. Mol Immunol 2006, 43:1340-1348.

47. Krasnov A, Koskinen H, Pehkonen P, Rexroad CE, Afanasyev S, Molsa H: Gene expression in the brain and kidney of rainbow trout in response to handling stress. BMC Genomics 2005, 6:3.

48. Jones SR: The occurrence and mechanisms of innate immunity against parasites in fish. Dev Comp Immunol 2001, 25:841-852

49. Palaksha KJ, Shin GW, Kim YR, Jung TS: Evaluation of non-specific immune components from the skin mucus of olive flounder (Paralichthys olivaceus). Fish Shellfish Immunol 2008, 24:479-488.

50. Maki JL, Dickerson HW: Systemic and cutaneous mucus antibody responses of channel catfish immunized against the protozoan parasite Ichthyophthirius multifiliis. Clin Diagn Lab Immunol 2003, 10:876-881.

51. Hansen JD, Landis ED, Phillips RB: Discovery of a unique Ig heavy-chain isotype $(\lg T)$ in rainbow trout: Implications for a distinctive B cell developmental pathway in teleost fish. Proc Natl Acad Sci USA 2005, 102:6919-6924.

52. Danilova N, Bussmann J, Jekosch K, Steiner LA: The immunoglobulin heavy-chain locus in zebrafish: identification and expression of a previously unknown isotype, immunoglobulin Z. Nat Immunol 2005, 6:295-302.

53. Tadiso TM, Lie KK, Hordvik I: Molecular cloning of IgT from Atlantic salmon, and analysis of the relative expression of tau, $\mathrm{mu}$, and delta in different tissues. Vet Immunol Immunopathol 2011, 139:17-26.

54. Yasuike M, de Boer J, von Schalburg KR, Cooper GA, McKinnel L, Messmer A, So S, Davidson WS, Koop BF: Evolution of duplicated IgH loci in Atlantic salmon, Salmo salar. BMC Genomics 2010, 11:486.
55. Zhang YA, Salinas I, Li J, Parra D, Bjork S, Xu Z, LaPatra SE, Bartholomew J, Sunyer JO: IgT, a primitive immunoglobulin class specialized in mucosal immunity. Nat Immunol 2010, 11:827-835.

56. Hamuro K, Suetake H, Saha NR, Kikuchi K, Suzuki Y: A teleost polymeric Ig receptor exhibiting two Ig-like domains transports tetrameric IgM into the skin. J Immunol 2007, 178:5682-5689.

57. Kaetzel CS: The polymeric immunoglobulin receptor: bridging innate and adaptive immune responses at mucosal surfaces. Immunol Rev 2005, 206:83-99.

58. Phalipon A, Corthesy B: Novel functions of the polymeric Ig receptor: well beyond transport of immunoglobulins. Trends Immunol 2003, 24:55-58.

59. Hamre LA, Glover KA, Nilsen F: Establishment and characterisation of salmon louse (Lepeophtheirus salmonis (Kroyer 1837)) laboratory strains. Parasitol Int 2009, 58:451-460.

60. Olsvik PA, Lie KK, Jordal AE, Nilsen TO, Hordvik I: Evaluation of potential reference genes in real-time RT-PCR studies of Atlantic salmon. BMC Mol Biol 2005, 6:21.

doi:10.1186/1471-2164-12-141

Cite this article as: Tadiso et al:: Gene expression analyses of immune responses in Atlantic salmon during early stages of infection by salmon louse (Lepeophtheirus salmonis) revealed bi-phasic responses coinciding with the copepod-chalimus transition. BMC Genomics 2011 12:141.

\section{Submit your next manuscript to BioMed Central and take full advantage of:}

- Convenient online submission

- Thorough peer review

- No space constraints or color figure charges

- Immediate publication on acceptance

- Inclusion in PubMed, CAS, Scopus and Google Scholar

- Research which is freely available for redistribution

Submit your manuscript at www.biomedcentral.com/submit
Biomed Central 